University of Rhode Island

DigitalCommons@URI

Open Access Dissertations

2017

\title{
A Study of Chinese Consumer Preferences for Sustainably Farmed Seafood
}

Chao Zou

University of Rhode Island, zorrozouchao@gmail.com

Follow this and additional works at: https://digitalcommons.uri.edu/oa_diss

\section{Recommended Citation}

Zou, Chao, "A Study of Chinese Consumer Preferences for Sustainably Farmed Seafood" (2017). Open Access Dissertations. Paper 655.

https://digitalcommons.uri.edu/oa_diss/655

This Dissertation is brought to you for free and open access by DigitalCommons@URI. It has been accepted for inclusion in Open Access Dissertations by an authorized administrator of DigitalCommons@URI. For more information, please contact digitalcommons-group@uri.edu. 


\section{A STUDY OF CHINESE CONSUMER PREFERENCES}

FOR SUSTAINABLY FARMED SEAFOOD

BY

CHAO ZOU

A DISSERTATION SUBMITTED IN PARTIAL FULFILLMENT OF THE REQUIREMENTS FOR THE DEGREE OF

DOCTOR OF PHILOSOPHY

IN

ENVIRONMENTAL AND NATURAL RESOURCE ECONOMICS

UNIVERSITY OF RHODE ISLAND 
DOCTOR OF PHILOSOPHY DISSERTATION

OF

CHAO ZOU

\section{APPROVED:}

Dissertation Committee:

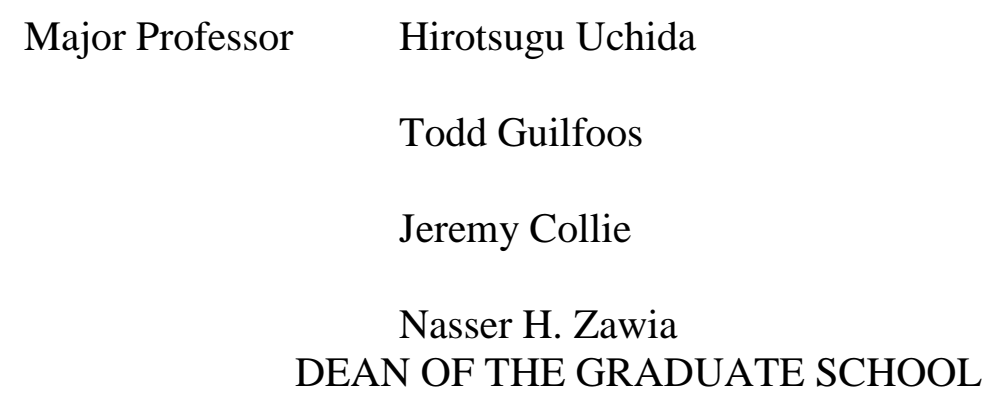

UNIVERSITY OF RHODE ISLAND

2017 


\begin{abstract}
Sustainable seafood programs have developed and evolved for approximately two decades as a market-based mechanism to complement the traditional "command and control" fishery management scheme. In some cases, they have successfully incentivized fishmen/fish farmers around the world to implement more environmentally sustainable production practices. It is not a perfect system capable of solving every fishery management issue immediately, but it is unequivocally one of the most promising mechanisms to slow down the degradation of wild fishery stocks or reduce environmental impacts from aquaculture, while improving the resilience of coastal fishery communities. As wild fishery stocks continue to decline, aquaculture production is becoming the main global seafood source. There is also increased awareness and importance of environmental impacts and consumer preferences of farmed seafood.

China is the largest producer and consumer of farmed seafood; thus, aquaculture sustainability is an important concern of both the Chinese government and its seafood industry. The promotion of sustainably farmed seafood, however, has not recently been successful in China. Some reasons could be the ineffectiveness of marketing strategies and lack of consumer awareness. This dissertation makes use of the welldeveloped Chinese online retail market and an experimental auction to conduct three studies evaluating the impact of the country of origin, eco-labels, and certification standards information on consumer preferences for farmed seafood. By incorporating consumers' subjective perceptions of quality, food safety, and eco-friendliness, we
\end{abstract}


were able to allocate consumer willingness to pay (WTP) for a product into basic product attributes.

Combining three studies draws the following conclusions. Among farmed seafood products, imported seafood is the Chinese consumers' first choice when there is no safety information. With guaranteed food safety, a higher price premium is generated for domestic farmed seafood, but not for imported. An eco-label does not generate a price premium in the current market, but consumers are willing to pay for it as long as they are informed of the public benefits of sustainable certification. Private and public benefit information, together, can significantly increase consumer WTP for sustainably farmed seafood, especially regarding safety and eco-friendliness. In sum, this thesis confirms the significant potential of the sustainably farmed seafood market in China and suggests seafood producers and retailers participate in sustainable seafood programs. 


\section{ACKNOWLEDGMENTS}

The pursuit of a Ph.D. degree is a very special journey in my life, and I am glad I have spent my most valuable years on this. The appreciation should be firstly given to Dr. Hirotsugu Uchida, my major advisor, who provided me the opportunity to join the Ph.D. program in the Department of Environmental and Natural Resource Economics at the University of Rhode Island. Dr. Uchida has been a great teacher in classes, mentor in research, and friend in life since the very beginning. His knowledge and wisdom shows me the path to a qualified student and a responsible researcher.

I would like to express my appreciation to all my dissertation committee members, Dr. Todd Guilfoos, Dr. Jeremy Collie, and Dr. Cathy Roheim, and defense Chair, Dr. David Bidwell. They provide me timely and consistent support and guidance on my studies and dissertation writing in the past few years. It is my honor to work with them and advised by them. I would also like to thank my former advisor, Dr. Benrong Peng from Xiamen University, who has been providing me advisement throughout my dissertation research.

A lot of thanks are given to ENRE faculties, staff and friends. I want to thank them for helping me develop research ideas, choose methods, interpret results and present the final work. Their comments and advices make a great contribution to my dissertation. I want to thank Barbara S. Gronstrom-Smith for contributing a significant amount of time editing my dissertation draft. I want to thank our best office support: Judy Palmer, Dennis Foley, and Ben Morris. They helped me process numerous files and never rejected any of my requests. Their hard work makes my graduate school life in a foreign country much easier. 
I want to thank all my friends in China who have lent me good hands in designing and completing my auction experiments in Xiamen and Beijing. I would love to thank YMCA Xiamen and Greenpeace Beijing for providing office space for the experiments; thank Dr. Chengliang Wu for his kindly financial support on some of my transportation and lodging in Beijing; thank Ms. Hanhan and ChinaBlue Sustainability Institute in Hainan for providing accommodation and research insights in Chinese sustainable seafood industry.

Most importantly I want to thank my family. My parents have always been my biggest supporters in any decision I made, financially and emotionally. Thank David Floyd and Marjory Stevens for treating me like a family member since my very first day in Rhode Island. Last, but not least I want to thank my dearest girlfriend Mengjie Xie. Her love and assistance has accompanied me through the hardest times in research and in life. I could not have accomplished this work without her. 


\section{TABLE OF CONTENTS}

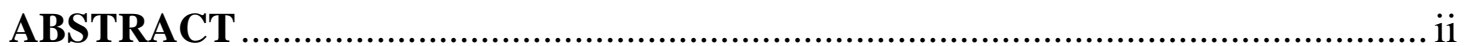

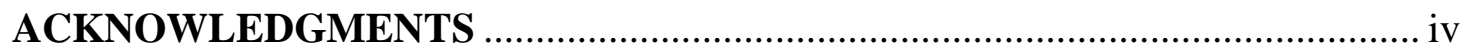

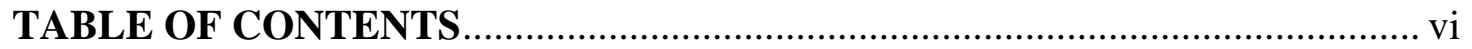

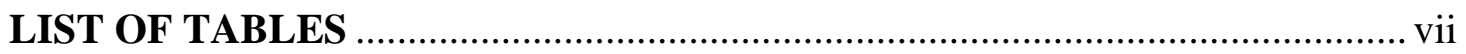

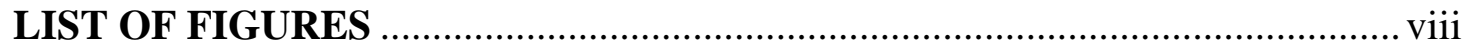

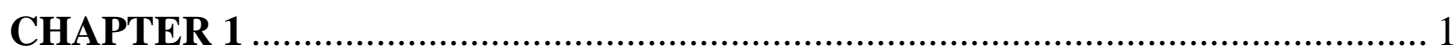

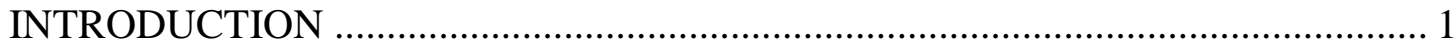

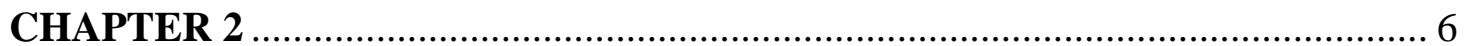

ASSESSING THE IMPACT OF ONLINE RETAILERS’ INFORMATION ON THE PRICE OF SUSTAINABLY FARMED SEAFOOD ................................. 6

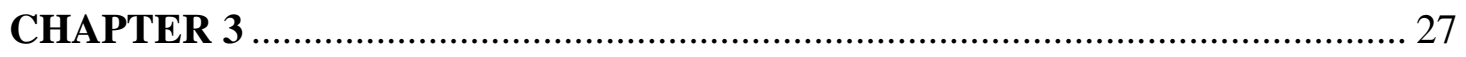

THE EFFECTS OF SUSTAINABILITY CERTIFICATION INFORMATION ON CHINESE CONSUMER WILLINGNESS TO PAY FOR FARMED SEAFOOD

CHAPTER 4 61

ESTIMATION OF CHINESE CONSUMER WILLINGNESS TO PAY FOR THE QUALITY, SAFETY AND ECO-FRIENDLINESS OF SUSTAINABLY

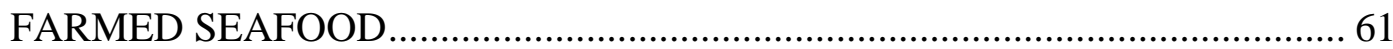

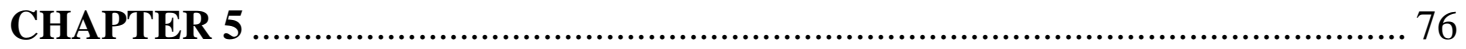

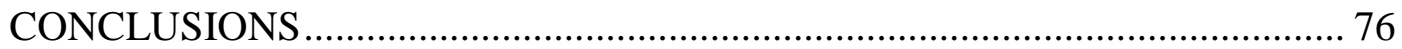

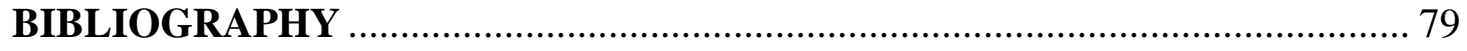




\section{LIST OF TABLES}

TABLE

PAGE

Table 2.1. Product Attributes and Description........................................................... 25

Table 2.2. Model Coefficients Estimation Results ................................................... 26

Table 3.1. Distribution of Participant Demographics ............................................... 48

Table 3.2. Auction Experiment Design ................................................................... 49

Table 3.3. Public and Private Benefit Information ............................................. 51 -52

Table 3.4. Summary Statistics of the Main Variables................................................. 53

Table 3.5. T-test for Price Differences of Imported/Domestic and Eco-labeled/Non-

labeled Products by Information Treatment............................................................ 54

Table 3.6. Impact of Information on Consumer WTP by Product Category ............... 55

Table 3.7. T-test for Price Premium of an Eco-label by Country of Origin and

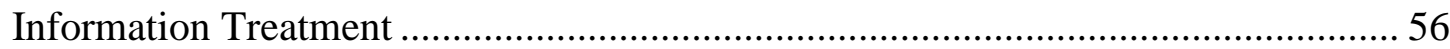

Table 3.8. T-test for Price Premium for Information by Product Category ................. 57

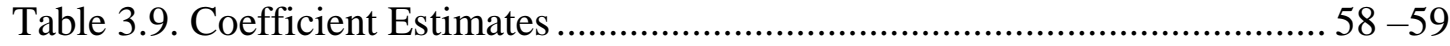

Table 3.10. T-test for Price Premium for Information by Product Category Using

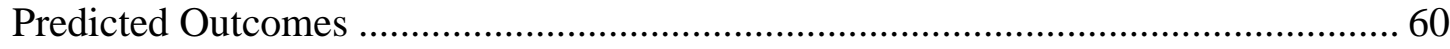

Table 4.1. Summary Statistics of Main Variables....................................................... 72

Table 4.2. Consumer WTP for Quality, Safety, and Eco-friendliness by Information

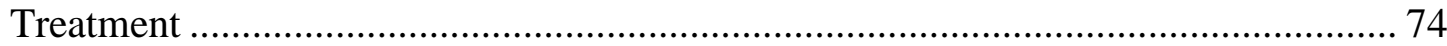




\section{LIST OF FIGURES}

FIGURE

PAGE

Figure 2.1. Comparison of Global Aquaculture and Wild Seafood Production. ........ 24

Figure 3.1. An Application of Maslow's Hierarchy of Needs to Seafood

Figure 3.2. Display Photos Used in the Experiment ........................................... 50

Figure 4.1. Summary of Consumer Perceptions and Bids by Product Type and

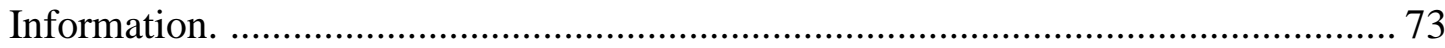




\section{CHAPTER 1}

\section{INTRODUCTION}

As the world's largest seafood producer and consumer, China needs a more sustainable seafood production system, as well as a more environmentally friendly seafood market. China has a coastline of 14,500 kilometers $(\mathrm{km})$, a little less than the $19,924 \mathrm{~km}$ of the US coastline (CIA 2017). If the offshore islands are included, China's coastline increases to $32,000 \mathrm{~km}$, with an Exclusive Economic Zone of 3,880,000 square km (Chen and Zhang 2009). Wide extended continent shelves, multiple river inputs, and the interaction of cold and warm currents provide China with rich fishery resources. Historically, China had four major fishing grounds with more than twenty high-yield species (Chen 2009; Chen 2014). However, after two decades of heavy exploitation in the 1980s and 1990s, traditional high-yield species, like little yellow croaker (Pseudosciaena polyactis) and large yellow croaker (Larimichthys crocea), in Yellow Sea and East China Sea almost became extinct. Today, most remaining fisheries rely on pelagic species and lower trophic-level fish like sardines, anchovies, mackerel, crustaceans, and mollusks (Chen 2014). However, FAO fishery statistics indicate that China has been consistently landing more than 10 million tons (MT) of marine fish, crustaceans, and mollusks since 1995, reaching an historic production of 15 MT in 2015, accounting for $19 \%$ of global catch (FAO 2016). Although China's marine fishery landings have remained high over the past decade, there is an obvious trend of decline in fish size and diversity. A recent 
Greenpeace investigation indicates that at least $30 \%$ of fish landings in China were at the juvenile stage or younger; half of which were from non-selective bottom trawlers. Within those immature fish, 96 of 218 species had considerable economic value if allowed to mature. In 2014, an estimated 2.22 MT of small-sized marine fish were ground into fishmeal, and another 4.95 MT were used in aquaculture (Greenpeace 2017). More sustainable fishery production and market systems need to be established in China to address the issues that lead to the collapsing Chinese inshore fisheries.

Along with the depletion of wild fisheries over the past two decades, China has experienced a rapidly growing economy and increased seafood demand. From 1995 to 2015, China’s GDP soared from US \$734,548 million to US \$11,064,664 million (The World Bank 2017). During the same period, China's total seafood consumption increased from 26 to $50 \mathrm{MT}$, with nearly all of the increase derived from the aquaculture sector (FAO 2017).

China's aquaculture has played an extremely important role in supporting its domestic economy and securing food supplies. The history of aquaculture in China dates back 3000 years, with Asian carp as the first cultivated species. Marine species farming, or mariculture, started about 50 years ago. The expansion of mariculture has flourished over the past decade, as wild stocks gradually started to decline and domestic seafood demand increased rapidly. Mariculture in China covers a range of products, including aquatic plants, crustaceans, shellfish, and finfish. Crustaceans have historically commanded the highest unit price. 
Aquaculture in China has created a series of environmental and social issues that have been ignored for a long time. One of the biggest problems is due to the use of wild-stock based fishmeal in aquaculture. China provides more than $50 \%$ of world aquaculture products, but at the same time it has consumed at least one MT of fishmeal every year since 2000 (Han et al. 2016). Due to the inefficiency of feeding methods and low conversion ratio for carnivores in aquaculture, a large number of wild fish were wasted. China needs more sustainably sourced fishmeal and plantbased fishmeal, and fish farmers need to improve their farming practices, like adopting more accurate feeding techniques. This will help mitigate the intense pressure on China's wild fish stocks.

Another issue affecting farmed seafood in China is the overuse of antibiotics. The pursuit of maximum unit production often leads farmers to intensive ponds or cages and excessive feeding. Protein residues from fishmeal can heavily contaminate the water during the summer months and increase the chance of serious disease. Large amounts of antibiotics are often mixed with fishmeal to prevent disease outbreaks. Overdosing will not only increase drug residues within the seafood but also damage the surrounding waters and wetlands through the effluent of wastewater. Fortunately, a number of Chinese fish farms have already acquired sustainable aquaculture certifications, such as Best Aquaculture Practices (BAP) and Aquaculture Stewardship Council (ASC) certification. These producers were initially certified to gain market access of Western countries like the UK and US, but in the past few years, they reverted to the Chinese domestic market due to intensified competition in international markets and increasing demand from the Chinese domestic market. 
To date, a limited number of eco-labeled domestic seafood products can be found in the Chinese market. Chinese certified producers hesitate to maintain sustainable standards for the domestic market because they are unsure about Chinese consumer preferences for these products. The concept of sustainable seafood is relatively new in China. Although constant efforts have been made by international non-governmental organizations, seafood companies, and the Chinse government, Chinese consumers have not responded positively, and market share and the acceptance of sustainable seafood remains low (Fabinyi 2016).

This dissertation investigates Chinese consumer preferences for sustainably farmed seafood from an economic point of view using both revealed preference and stated preference data. The study also provides marketing suggestions and policy implications to facilitate the promotion of sustainably farmed seafood in China. The research findings are summarized into three areas. First, seafood safety is the biggest concern for Chinese consumers. They prefer imported seafood when there is no safety information provided. However, when they have guaranteed safety, they select domestic seafood. Meanwhile, guaranteed safety can generate a high premium for domestic seafood versus products without a safety guarantee. But there is no such certification for imported seafood. Second, eco-friendliness does not generate a price premium in the current market, but consumers are willing to pay for it as long as they are informed with public benefit information. Third, fully explained certification information can significantly increase consumer WTP for sustainably farmed seafood, most of which is due to their changes in perception regarding safety and ecofriendliness. 
The remainder of this paper is arranged as follows. Chapter 2 investigates whether price premium exists, and the impact of information provided, of sustainably farmed seafood using online retailers' real market data. Chapter 3 uses an experimental auction method to estimate consumer WTP for sustainably farmed seafood under different information scenarios. Chapter 4 is an extension of Chapter 3. It incorporates consumers' subjective perceptions to estimate their WTP for the quality, safety, and eco-friendliness of sustainably farmed seafood. Chapter 5 concludes. 


\section{CHAPTER 2}

\section{ASSESSING THE IMPACT OF ONLINE RETAILERS' INFORMATION ON THE PRICE OF SUSTAINABLY FARMED SEAFOOD}

\section{Introduction}

In an addition to wild capture fisheries, aquaculture makes a valuable contribution to providing high-quality, affordable protein to the world, especially in developing countries. It has, however, created intensive pressure on natural resources and the environment. FAO statistics indicate that total global aquaculture production (including both saltwater and freshwater) has exceeded capture fisheries since 2013, and global marine aquaculture has increased rapidly over the past two decades (FAO 2011). Figure 2.1 shows the rapidly growing trend of global aquaculture production from 1950 to 2015 . FAO projects that aquaculture will be responsible for almost twothirds of the fish we eat by 2030 .

While enjoying the benefits of this rapidly growing aquaculture industry, it is critical to have a clear vision of its environmental impacts and correctly relay this information to the general public. Cao et al. (2015) found that Chinese aquaculture consumed 1.4 MT of fishmeal in 2012, equivalent to 6.7 MT of live-weight forage fish (e.g., anchovy, sardine, herring, and menhaden). Extend this number to the global aquaculture industry, and it is estimated that $20 \mathrm{MT}$ of live-weight fish are processed into fishmeal every year, accounting for more than $20 \%$ of total global wild capture production. At the same time, it should be noted that traditional farming practices have 
heavily damaged the natural environment. Destructive farm construction often decimates coastal wetlands, such as mangroves and saltmarshes. The effluent of untreated wastewater that contains fishmeal residue could cause eutrophication in the watershed. Overdosed antibiotics, drugs, and other chemical compounds could impair the health of the entire ecosystem.

The concept of sustainable aquaculture was created about a decade ago following a similar philosophy of sustainable wild fishery programs, such as MSC certification, but it has additional standards on seafood quality and safety. Although the number of sustainably certified aquaculture facilities and products is experiencing rapid growth, the amount of sustainable production accounts only for a small portion of global output. In 2010, only $4.2 \%$ of total aquaculture production was certified (Jonell et al. 2013). A more recent report from Global Good Agricultural Practice, a world leading sustainable aquaculture certifier, indicates that they have certified 2.1 of MT seafood, accounting for about $2 \%$ of global production. Jim Heerin, the president of BAP Management, indicated that they certified less than one MT of production in 2015. ASC, another sustainable aquaculture giant, supplied about $0.5 \mathrm{MT}$ of seafood to the market in 2015 (ASC 2017). An optimistic estimate is that $10 \%$ of farmed seafood has been sustainably certified. Thus, the impacts of sustainable aquaculture on the natural environment and resources remain limited. It is not because of deficiencies in sustainable standards, but due to a constrained production quantity caused by a complicated certification process and high costs (Belton et al. 2010; Ponte 2012; Bush et al. 2013; Gutierrez et al. 2016). In other words, producers and retailers, especially in developing countries, do not have enough economic incentive to become engaged in 
sustainable programs. More producers and retailers are needed to increase the impact of sustainably farmed seafood. More importantly, consumer recognition and confidence is needed for further development of the entire industry.

This chapter takes advantage of the well-developed Chinese online seafood market, aiming to understand the impacts of seafood quality, safety, and ecofriendliness information on market price, particularly on whether price premium exists for these attributes. Sustainably farmed seafood was introduced into the Chinese market about five years ago, and the online retail market is one of the key distribution channels. During the early stage of the movement, only a few imported products carried aquaculture eco-labels. Most domestic certified seafood products were exported to Western countries. But as demand gradually increased in mainland China, more local products started to carry aquaculture eco-labels. Market observations provide anecdotal evidence on the positive price premium for certified seafood, but it has not yet been determined whether these certified aquaculture products can generate a profit. Also, it is not certain whether there exists a premium for certification, country of origin, or other attribute information. With multiple standards on seafood quality, safety, and eco-friendliness, if aquaculture certification generates a significant price premium, to what attribute(s) should the premium be ascribed? To date, very little quantitative research has been conducted to answer these questions.

Another innovation of this research is to utilize sales price data and product descriptions from online retailers' websites. Online shopping is different from traditional shopping, where consumers can spend more time comparing products and evaluating the information provided by retailers. A highly competitive online retail 
market is a transparent trading platform where consumers can easily access information of various products and retailers in a few minutes, forcing retailers to update their prices frequently based on sales. A log-linear hedonic price model suggests that there is a $6.6 \%$ premium for imported products when there is no farming environment, safety, or eco-label information provided. When safety information is provided, results indicate a higher safety premium for domestic certified shrimp over imported. In sum, Chinese consumers place more trust in imported seafood when they have enough information to assist in decision making, but they still prefer domestic shrimp when there is a safety guarantee. To our surprise, eco-labels on websites have a negative impact on price.

This chapter is arranged as follows. The next section presents a brief literature review of related topics and indicates the contribution of this research. The third section describes the data structure, followed by model specification and estimation. Results and discussion are next, and the final section concludes and reports on policy implications.

\section{Background}

It is vital to sustainable seafood programs and the seafood industry to show the true effect of sustainability information on sustainable seafood price. Different methods are adopted by scholars depending upon data availability. In the early 2000s when sustainable seafood markets were becoming established, no market data was available, so stated preference methods were used more frequently. Using the contingent choice survey method, Wessells, Johnston, and Donath (1999) assessed the influence of 
certification on US consumer preferences for eco-labeled seafood. Johnston et al. (2000) measured the difference between US and Norwegian consumer preferences for organic, eco-labeled, and regular seafood using the choice survey method. Jaffry et al. (2004) evaluated consumer choices for quality and sustainably labeled seafood products in the UK through a choice experiment. Other researchers conducted similar analysis on agricultural and wood products (Loureiro, McCluskey, and Mittelhammer 2001a; O'Brien and Teisl 2004). All these hypothetical choice experiments conclude that consumers in Europe and the US are willing to pay a price premium for ecolabeled products, but no actual market premiums were estimated.

As more retailers committed to sustainable seafood, and consumers were exposed to the concept, market data subsequently became available for analysis. Roheim, Asche, and Santos (2011) found a 14.2\% price premium was paid for MSC-labeled products by UK consumers using retailer scanner data. In addition to a seafood ecolabel, Bronnmann and Asche (2016) found a price premium for brands and private labels using German scanner household panel data and concluded that private-label products were discounted by $20 \%$. However, the branded products and certified aquaculture products received substantial premiums.

Most previous research has focused on sustainable seafood products from the capture fisheries, and little attention has been paid to certified aquaculture products. Unlike wild fishery eco-labels, sustainable aquaculture certification does not only require achievement of public benefits, like environmental impacts and fishery stocks, but also has standards to ensure consumer private benefits like food quality and safety. 
Thus, the impact of aquaculture eco-labels is, by definition, very different from that of wild fishery eco-labels.

This chapter uses online retailers' price and product information to evaluate the impact of information on Chinese consumer preferences. Detailed product descriptions from the websites ensure the delivery of information to consumers, especially for ecolabel information. Previous studies take the eco-label as one integrated attribute, while using online retail data can separate it into multiple basic attributes, like food quality, safety, and eco-friendliness. This is a substantial improvement for sustainable seafood attribute analysis, and the results can be more informative and useful.

\section{Data description}

White-leg shrimp (Penaeus vannamei) is used as the representative species for farmed seafood because it is one of the most commonly produced and consumed seafood in China and worldwide. White-leg shrimp is native to the eastern Pacific Ocean. It was first cultured in Florida, USA, using mated females from Panama in 1973. White-leg shrimp farming started in the Latin America in the 1990s, and began gaining popularity in a few Asian countries around 2000 due to its high productivity and low farming costs (approximately USD $2.5-3.0 / \mathrm{kg}$ for $P$. vannamei, compared to USD 3.0-4.0/kg for more extensive P. monodon culture) (FAO 2016). Currently, Ecuador and China are two of its biggest producers (Huntington and Hasan 2009; FAO 2011).

Two types of data were used in this research: (1). weekly online price data from different retailers collected through a price tracking website (manmanbuy.com) from June 17, 2016 to April 30, 2017, and (2) product attribute information collected 
through retailers' webpages. Sampled products are all frozen raw white-leg shrimp produced in either China or Ecuador. Some were certified as sustainable by a third party and some not. Table 2.1 displays the variables and a summary of the descriptive statistics.

In Table 2.1, product attribute information is divided into three blocks that fully capture product characteristics (Darby and Karni 1973; Ford, Smith, and Swasy 1988). The first block is search attributes. Consumers could evaluate these attributes through pre-purchase searching activities. Nearly all retailers provide this type of information on their product webpage, and it is easily verified. The second block is additional information provided by retailers to differentiate their products from others. These experience attributes are difficult are difficult to verify before purchasing, since only when the product is received or consumed, can the consumer discern the truthfulness of the information. The last block contains the credence attributes, which are the major focus of this research. These attributes build on consumer trust of the retailers and certifiers, and such information could possibly induce a price premium.

The search attributes were examined first. The most important variable, the dependent variable, is price. Originally, daily prices were collected from "manmanbuy.com," but the data were averaged into weekly prices because retailers usually adjust their prices once a week. There is no benefit to having repeated samples in the dataset. The average weekly price for all products is about 57 yuan/500 $\mathrm{g}$ (US $\$ 8 /$ pound). Whole shrimp comprises $66.8 \%$ of the samples; the rest are peeled. Shrimp size varies from small to jumbo. The criteria used are from the size chart in international trade. For whole shrimp, small is about $41-60$ count/pound, medium 31- 
40, large 21-30, and jumbo 16-20. For peeled shrimp, small is about 51-70 count/pound, medium 41-50, large 31-40, and jumbo 21-25. In this dataset, the average size is between medium and large, but closer to medium. Package size is another important factor that impacts retail price. Large-sized packages tend to have a lower price. Frozen shrimp sold online has an average weight of 1,179 grams (2.6 pounds). Product ratings can be found on the product webpage, which is automatically generated by the system and cannot be altered by retailers. It serves as a comprehensive evaluation for both the product and retailer services. The most recent scores were used to represent product ratings for two reasons. First, it is extremely difficult to acquire daily ratings of each product from retailers or Alibaba.com (the online retail platform). Second, since most products have been launched for a long time and received tens of thousands of reviews, product ratings would not change significantly during our research period. This is a control variable for retailers' unobserved heterogeneity.

The experience attributes are the retailers' statements regarding freshness, product weight, and ice glazing rate. Basically, they are describing products quality, which can be verified by consumers upon arrival. These attributes are dummy variables that take the value 1 if retailers claim such an attribute on the website and 0 otherwise. Usually different retailers use similar descriptions and images to illustrate these characteristics. For example, they use phrases such as "Fresh out of the water, frozen immediately to $-30^{\circ} \mathrm{F}$, fast shipping and guaranteed fresh at your door, and full refund if not satisfied" to describe the freshness of their products. Ice rate is a very specific attribute that many consumers may not notice. Normally, frozen seafood is 
glazed with a layer of saltwater and chemicals to maintain moisture during shipping. But this reduces the actual product weight. About $10 \%$ of the products guarantee that the shrimp will meet the displayed package weight after defrosting. However, less than $3 \%$ of the products indicate the actual ice rate contained in the package.

Five credence attributes are included in the analysis, all of which are dummy variables. The first one is "imported." Imported products have a special appeal to Chinese consumers regardless of origin because stringent import custom's inspection is viewed as insurance for product quality and safety. Frequent domestic food safety incidents destroy consumer confidence in domestic products. Thus an "imported" label is expected to have some impact on the price, and $60 \%$ of our samples are from Ecuador.

Safety is another key factor that impacts the price. As mentioned above, food safety is extremely important in China. Government and retailers have invested a great amount of resources to improve food safety during production and retailing. Typical safety information displayed by online retailers is a copy of safety inspection certificate, such as Hazard Analysis Critical Control Point (HACCP). According to the FDA (2017) definition, "HACCP is a systematic preventive approach to food safety from biological, chemical, and physical hazards in production processes that can cause the finished product to be unsafe, and designs measurements to reduce these risks to a safe level." Additional presentation of safety information includes descriptive statements guaranteeing no antibiotic use. About $40 \%$ of the products in the dataset contain safety information. Farm environment is mentioned by $32 \%$ of products, 
which emphasize the water quality at the farm. It is a vague concept that can be viewed as a representation of both quality and safety.

The variable "eco-label" indicates whether or not the product webpage explicitly displays a sustainable seafood certification label like, "BAP." Only 9\% of products display an eco-label. However, about $38 \%$ of the products in the dataset are actually sustainably certified. The reason why retailers hesitate to display an eco-label on a Chinese website may be the lack of Chinese consumers' confidence in and knowledge of the label, as well as additional costs of using them. Most domestic producers get certified because they need such designation for international market access. Regarding the domestic market, this certification was not as important as in the Western market.

An additional variable "certified" was added to capture the product's quality improvement through the certification program. It is not an attribute for ecofriendliness, since consumers are not informed of the certification. The only way for the "certified" attribute to impact consumers is through the repurchase behavior caused by the product consumption experience. In other words, products that are certified but do not contain an eco-label are assumed to be of higher quality, attracting consumers to purchase again and pay higher prices.

\section{Model specification and estimation}

Following previous research by Roheim, Asche, and Santos (2011) and Bronnmann and Asche (2016), a log-linear hedonic price model was adopted for the analysis. This price model was developed by Lancaster (1966) and Rosen (1974) to evaluate 
consumer demand for product attributes. It is widely used in the assessment of nonmarket value of environmental and natural resources (Ready and Abdalla 2005; Sander and Polasky 2009; Gopalakrishnan et al. 2011), as well as product attributes (Sogn-Grundvåg, Larsen, and Young 2014; Wang 2016). The value of a pricedetermining attribute can be evaluated by the presence or absence of the attribute within the product (Wessells 2002). Thus, a general model can be written as following:

$$
\text { Price }_{i t}=f\left(\text { Attribute }_{1}, \ldots \text { Attribute }_{n}\right) \text {, }
$$

where Price $_{i t}$ is product $i$ 's price at time period $t$, and is determined by a function of $n$ attributes.

The functional model is shown as:

$$
\begin{aligned}
\ln _{\left(\text {price }_{i t}\right)=} & \alpha+\beta_{1} \text { package_size }_{i}+\beta_{2} \text { whole }_{i}+\beta_{3} \text { package_size }_{i} * \text { whole }_{i} \\
& +\beta_{4} \text { freshness }_{i}+\beta_{5} \text { full_weight }_{i}+\beta_{6} \text { ice_rate }_{i}+\beta_{7} \text { imported }_{i} \\
& +\beta_{8} \text { safety }_{i}+\beta_{9} \text { farm }_{i}+\beta_{10} \text { eco_label }_{i}+\beta_{11} \text { certified }_{i} \\
& +\beta_{12} \text { imported }_{i} * \text { safety }_{i}+\beta_{13} \text { imported }_{i} * \text { certified }_{i} \\
& +\sum_{s=1}^{3} \delta_{S} \text { shrimp_size }_{i s}+\sum_{r=1}^{4} \theta_{r} \text { rating }_{i r}+\sum_{c=1}^{6} \varphi_{c} \text { city }_{i c}+\varepsilon_{i t}
\end{aligned}
$$

where $\ln \left(\right.$ price $\left._{i t}\right)$ is the price of product $i$ at time period $t$ in logarithmic form;

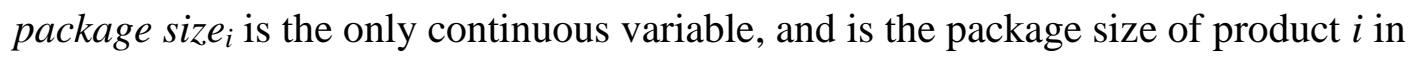
100 grams. All other variables are dummies. Safety , farm $_{i}$, and eco-label $_{i}$ are dummy variables indicating whether or not the website provides product safety information, farm environmental condition information, and an eco-label respectively. Certified $_{i}$ is a variable that indicates whether or not product $i$ has achieved certification even if this 
information is not shown on the website. Variables such as import, whole, freshness, full_weight, ice_rate, Shrimp_size, rating and city are also controlled as dummies. Three interaction terms are added to test the cross effects of those variables. Some other factors, like product brand and retail brand, are not included in the model since they are highly collinear with some independent variables. $\varepsilon_{i t}$ is an individual specific error term that contains all other factors that are not included in the model.

$\alpha$ is the constant term, and $\beta, \delta, \theta$, and $\varphi$ are variable coefficients to be estimated.

Because this is a log-linear model, each estimated coefficient can be interpreted as the percentage marginal value of the attribute. For example, $\beta_{1}$ means that a 100 gram increase in package weight will increase $\frac{\beta_{1}}{100} \%$ in total price, ceteris paribus (this condition also applies to the following statements); $\beta_{8}$ can be interpreted as the presence of safety information on the website can increase/decrease $\frac{\beta_{8}}{100} \%$ in price, or consumers are more/less willing to pay $\frac{\beta_{8}}{100} \%$ price for the safety information on the website. Interaction terms represent the effect of one variable on the other. For example, $\beta_{3}$ can be interpreted as the price change rate difference between whole shrimp and peeled shrimp when package size increases by 100 grams. $s, r$, and $c$ are indices of the variables. There are four shrimp sizes, thus three dummies. Product ratings could be considered continuous variables, but there are only five different values so we created four dummies. Retailer locations are represented by six dummies.

Two estimation models are displayed in Table 2.2; one without interaction terms and one with them. The models were estimated using STATA software version 12. Several tests were conducted to ensure the efficiency and consistency of the results. First, homoscedasticity was rejected by the Breusch-Pagan/Cook-Weisberg test for 
both models. A clustered variance robust estimation was then used to correct for heteroscedasticity. Collinearity between independent variables was tested by checking the variance inflation factors (VIF). VIFs in Model 1 are under 10 with for variables, while interaction terms in Model 2 show larger VIFs. For adjusted R-square, Model 2 has a higher value. Finally, after checking the magnitudes and signs of the coefficient estimates, Model 2 contains more insightful information and a better explanation due to the inclusion of interaction terms. Thus, it is used to interpret regression results in the following section.

\section{Results and discussion}

The results will be explained block by block. An F-test of the model rejected the null hypothesis that all estimated coefficients are jointly equal to zero.

\section{Search attributes:}

Products with large packages usually have lower unit prices. Here, since both whole and peeled shrimp are considered, the effects of package size on price are different. Together with the interaction term pack*whole, when it comes to peeled shrimp (whole $=0$ ), there is no significant price impact due to package size. For whole shrimp (whole=1), when package size increases by 100 grams, price decreases by $2.8 \%$, all else equal. This is reasonable because peeled shrimp are usually sold in small packages, $200 \mathrm{~g}$ or $500 \mathrm{~g}$, while whole shrimp packages can contain from $200 \mathrm{~g}$ to 2000 . 


\section{Experience attributes}

No experience attributes were expected to have positive impacts on product prices because they could be verified immediately after receiving the package. A retailers' guarantee does not apply to returning customers, rather the first-time purchasers. New consumers do not comprise the major customer group of a well-established online market. Results indicate that a full-weight guarantee has a small positive premium of 3.7\%. Neither a freshness guarantee nor ice glazing rate information has a significant impact on prices. For most repeat buyers, this type of information is irrelevant.

\section{Credence attributes:}

As mentioned earlier, credence attributes are difficult to test or verify through normal consumption. Thus, the information provided by the retailers is very important for consumer's decision-making. For the imported attribute, both safety and certified information can be interpreted together. Table 2.2 shows that without safety information $($ safety $=0)$ or certification $($ cert $=0)$, imported products have a $6.6 \%$ price premium over domestic products. When safety information is provided (safety=1), but the products are not certified (cert $=0$ ), domestic products are $37 \%$ more expensive than imported products. When there is no safety information (safety=0) but the products are certified (cert=1), consumers are willing to pay a $14.7 \%$ price premium for imported products. Finally, when there is safety information (safety=1) and the products are certified (cert=1), there is a $29 \%$ price premium for imported products. In conclusion, providing safety information is critical for domestic products. When there is no safety information, consumers generally prefer imported products. 
For domestic products, safety information generates a $36 \%$ premium, while it does not generate a positive price premium on imported products. On the whole, there is a $44 \%$ premium difference between domestic and imported seafood in terms of safety information. Certification has no significant impact on domestic products, but generates an $8 \%$ price premium on imported shrimp. This means that imported, certified shrimp are of higher quality and consumers have realized this through repeated consumption. For certified domestic shrimp, consumers did not perceive a significant difference in quality from uncertified shrimp; thus, there is no premium found.

Results also indicate a $8.4 \%$ premium when retailers provide positive information about the farm environment, but no positive effect is observed for an eco-label. The descriptive words that retailers use for farm environment are always vague, and appealing pictures seem very attractive to consumers, leading to the assumption that the farm environment is related to shrimp quality and safety. Since safety information has already been included, the farm environment might be more relevant to quality. Only $9 \%$ of products display an eco-label and it a negative effect on shrimp price. It is probably because Chinese consumers are still very unfamiliar with the concept and have some doubt about the credibility of the producers and certifiers. This lack of trust is very critical to the expansion and development of sustainable seafood in China.

\section{Other attributes:}

Other attributes, such as shrimp size, product rating, and retailer location are also included in the regression. Since they are not our main focus, we will only summarize 
them here. Ratings do not seem to impact prices significantly. Only products with a $100 \%$ score have an $8 \%$ price premium. Shrimp sizes impact price significantly. Medium, large, and extra-large shrimp have a price premium of 4, 9, and 25\%, respectively, over small-sized shrimp. In terms of location, with Beijing as the base, Dalian, Guangzhou, and Ningbo are not significantly different from Beijing. Hangzhou and Shanghai are 5\% cheaper, which may be due to their better geographic location and more advanced logistics industry.

\section{Conclusion}

Promotion of sustainable seafood has never been an easy job anywhere in the world. It requires a long-term commitment from all players within the supply chain, as well as awareness and acceptance from consumers. Initiating a new product campaign without support from consumers is almost an impossible mission. Recent research shows that North American consumers do not have enough incentives to pay a premium for sustainable seafood. Corporate efforts are mostly a social responsibility created by mainstream retailers to improve their image and reputation. So far, very limited positive environmental impact has been generated through programs or campaigns.

Thus, it is not suggested to promote sustainable seafood applying marketing strategies in Western world to China, especially when Chinese consumers have lower incomes and are more sensitive to food prices. Fostering consumer awareness and generating consumer demand are the keys to the success in the Chinese market.

This study suggests that seafood safety is the biggest concern of Chinese consumers. For domestic shrimp, safety information generates a 36\% price premium, 
while safety information does not affect the price for imported products. When there is no safety information, there is a 14.6 and $6.6 \%$ price premium for imported certified products and non-certified products over domestic products, respectively.Good farming environment also generates a $8 \%$ premium. These results tell retailers to focus more on seafood quality and safety, regardless of source. It is also a good strategy to combine sustainability with quality and safety information for certified farmed seafood instead of simply pushing the relatively new concept of sustainability to Chinese consumers. At the policy level, the Chinese government has already noticed the difference between export-oriented and domestic-oriented production and launched new policies last year to ensure they were from the same production line with consistent labelling and standards. This may bolster Chinese consumer confidence in domestic products, but only the passing of time will demonstrate their effectiveness and impacts on Chinese consumer behavior.

Some concerns of this research fall on consumer perception of online retailers' information. Because every piece of information is provided by retailers, consumers' opinions could not be assessed. Their level of understanding of this information is uncertain. The eco-label information is a very typical example. One cannot deny the contribution of eco-labels, simply because there are no significant effects from the regression. Most Chinese consumers are not familiar with the standards and values associated with these labels, as they are basically some unrecognized symbols. If more explanatory information is provided, consumers may elicit different responses. The following chapters use stated preference methods, like experimental auctions, which 
will capture both consumer WTP and perceptions on the information they receive. More precise conclusions can be formulated through this type of research. 


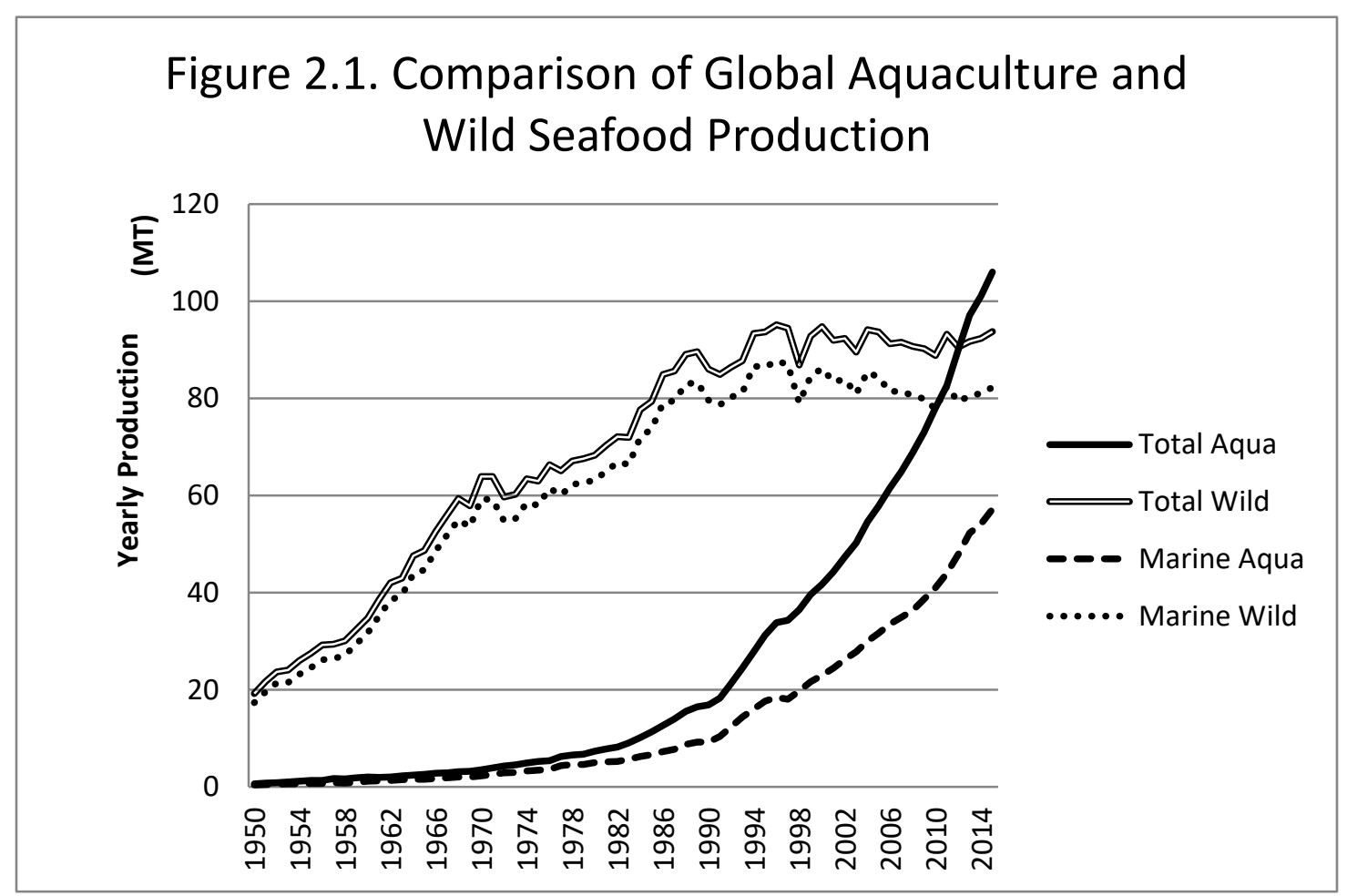

Data source: FAO Fishery Statistics 2017.

Notes: Total Aqua indicates total global aquaculture production; Total Wild indicates total global wild fisheries production; Marine Aqua indicates global marine aquaculture production; Marine Wild indicates global marine wild fisheries production. 
Table 2.1. Product Attributes and Description

\begin{tabular}{|c|c|c|c|}
\hline Attribute & Mean & $\begin{array}{l}\text { Std. } \\
\text { Dev. }\end{array}$ & "Description \\
\hline \multicolumn{4}{|l|}{ Search attribute } \\
\hline Price & 57.732 & 17.039 & Yuan $/ 500 \mathrm{~g}$, weekly average price \\
\hline Shrimp size & 2.352 & 0.871 & $\begin{array}{l}\text { Small }=1, \text { Medium }=2 \text {, Large }=3, \text { Jumbo }=4 \\
\text { treated as dummies in regression }\end{array}$ \\
\hline Package size & 1179.086 & 771.498 & Grams \\
\hline Whole & 0.668 & 0.471 & Whole $=1$, peeled $=0$ \\
\hline Product rating & 97.304 & 1.628 & $\begin{array}{l}\text { Consumer rating of product; scale }=100 \\
\text { points }\end{array}$ \\
\hline \multicolumn{4}{|c|}{ Experience attribute } \\
\hline $\begin{array}{l}\text { Freshness } \\
\text { guaranty }\end{array}$ & 0.790 & 0.408 & $\begin{array}{l}\text { Dummy variable, yes }=1 \text {, retailer's claim of } \\
\text { product freshness }\end{array}$ \\
\hline $\begin{array}{l}\text { Weight } \\
\text { guaranty }\end{array}$ & 0.104 & 0.306 & $\begin{array}{l}\text { Dummy variable, yes }=1 \text {, retailer's claim of } \\
\text { product weight }\end{array}$ \\
\hline Ice rate & 0.026 & 0.159 & $\begin{array}{l}\text { Dummy variable, yes }=1 \text {, webpage } \\
\text { description of ice glazing rate }\end{array}$ \\
\hline \multicolumn{4}{|c|}{ Credence attribute } \\
\hline Imported & 0.592 & 0.492 & $\begin{array}{l}\text { Dummy variable, yes }=1 \text {, imported from } \\
\text { Ecuador }\end{array}$ \\
\hline $\begin{array}{l}\text { Safety } \\
\text { information }\end{array}$ & 0.390 & 0.488 & $\begin{array}{l}\text { Dummy variable, yes }=1 \text {, webpage } \\
\text { description of product safety }\end{array}$ \\
\hline $\begin{array}{l}\text { Farm } \\
\text { environment }\end{array}$ & 0.322 & 0.468 & $\begin{array}{l}\text { Dummy variable, yes }=1 \text {, webpage } \\
\text { description of farming environment }\end{array}$ \\
\hline Eco-label & 0.090 & 0.286 & $\begin{array}{l}\text { Dummy variable, yes }=1 \text {, webpage } \\
\text { description of product eco-label }\end{array}$ \\
\hline Certified & 0.377 & 0.485 & $\begin{array}{l}\text { Dummy variable, yes }=1 \text {, Sustainability } \\
\text { certified by third party }\end{array}$ \\
\hline
\end{tabular}


Table 2.2. Model Coefficient Estimation Results

\begin{tabular}{|c|c|c|}
\hline Variable & $\begin{array}{c}(1) \\
\text { Price (in logs) }\end{array}$ & $\begin{array}{c}\text { (2) } \\
\text { Price (in logs) }\end{array}$ \\
\hline Constant & $\begin{array}{c}4.416^{* * *} \\
(0.023)\end{array}$ & $\begin{array}{c}4.315 * * * \\
(0.025)\end{array}$ \\
\hline \multicolumn{3}{|l|}{ Search attributes } \\
\hline Package size (100g) & $\begin{array}{c}-0.021 * * * \\
(0.001)\end{array}$ & $\begin{array}{c}0.001 \\
(0.004)\end{array}$ \\
\hline Whole shrimp (yes=1) & $\begin{array}{c}-0.199 * * * \\
(0.017)\end{array}$ & $\begin{array}{c}-0.076^{* * *} \\
(0.022)\end{array}$ \\
\hline Package size $\times$ whole shrimp & & $\begin{array}{c}-0.028^{* * *} \\
(0.004)\end{array}$ \\
\hline \multicolumn{3}{|l|}{ Experience attributes } \\
\hline Guaranteed fresh $($ yes $=1)$ & $\begin{array}{c}-0.051 * * * \\
(0.013)\end{array}$ & $\begin{array}{l}-0.014 \\
(0.015)\end{array}$ \\
\hline Guaranteed full weight (yes=1) & $\begin{array}{c}0.103 * * * \\
(0.016)\end{array}$ & $\begin{array}{l}0.037 * * \\
(0.015)\end{array}$ \\
\hline Ice glazing rate information (yes $=1$ ) & $\begin{array}{c}0.579 * * * \\
(0.066)\end{array}$ & $\begin{array}{c}0.045 \\
(0.034)\end{array}$ \\
\hline \multicolumn{3}{|l|}{ Credence attributes } \\
\hline Imported from Ecuador (yes $=1$ ) & $\begin{array}{l}-0.036 \\
(0.029)\end{array}$ & $\begin{array}{l}0.066^{* *} \\
(0.027)\end{array}$ \\
\hline Safety information (yes $=1$ ) & $\begin{array}{c}-0.099 * * * \\
(0.019)\end{array}$ & $\begin{array}{c}0.364 * * * \\
(0.065)\end{array}$ \\
\hline Farm environment information (yes $=1$ ) & $\begin{array}{c}0.107 * * * \\
(0.017)\end{array}$ & $\begin{array}{c}0.084 * * * \\
(0.015)\end{array}$ \\
\hline Eco-label on website $($ yes=1) & $\begin{array}{c}0.268 * * * \\
(0.039)\end{array}$ & $\begin{array}{c}-0.076^{* *} \\
(0.039)\end{array}$ \\
\hline Sustainable certification (yes $=1$ ) & $\begin{array}{c}0.062 * * * \\
(0.016)\end{array}$ & $\begin{array}{c}0.009 \\
(0.034)\end{array}$ \\
\hline Imported $\times$ safety & & $\begin{array}{c}-0.436 * * * \\
(0.068)\end{array}$ \\
\hline Imported $\times$ certified & & $\begin{array}{c}0.081 * * * * \\
(0.028)\end{array}$ \\
\hline Observations & 1,542 & 1,542 \\
\hline Adjusted R-squared & 0.738 & 0.745 \\
\hline $\operatorname{Pr}>\mathrm{F}$ & 0 & 0 \\
\hline
\end{tabular}

Notes: $* * * \mathrm{p}<0.01, * * \mathrm{p}<0.05$.

All variable information is collected from product websites, except for the sustainable certification variable. This is verified by the author through the producer websites, which most consumers will not access. Other control variables not reported in this table include shrimp size, product rating, and retailer location. 


\section{CHAPTER 3}

\section{THE EFFECTS OF SUSTAINABILITY CERTIFICATION INFORMATION ON CHINESE CONSUMER WILLINGNESS TO PAY FOR FARMED SEAFOOD}

\section{Introduction}

Sustainably farmed seafood was introduced to China several years ago, but Chinese retailers and producers are still facing great challenges marketing it to the general public (Fabinyi 2016). Since late 1990s, sustainable seafood programs, like certification and eco-labeling, have been successfully developed and promoted in Europe and North America as a market-based tool to complement the traditional "command and control" fishery management scheme (Wessells, Johnston, and Donath 1999; Johnston et al. 2001; Ponte 2012). However, the concept of sustainable seafood, especially farmed seafood, has not been well accepted in China despite almost constant effort dedicated to public education and supply chain engagement (Fabinyi 2012; Fabinyi and Liu 2016). The challenges can be summarized in two categories: consumer awareness and consumer acceptance, both of which are the key to the success of sustainable seafood programs (Wessells 2002). In major Chinese cities, such as Beijing and Shanghai, consumers have some awareness of green-labeled/ecolabeled $^{1}$ seafood, but they are willing to pay a premium only if additional food quality or safety information is provided (Xu et al. 2012; Fabinyi 2016). Chinese consumers are more concerned with the private benefits of certified seafood than those associated

\footnotetext{
${ }^{1} \mathrm{~A}$ green-label is a Chinese domestic food certification similar to organic certification, but with lower standards.
} 
with environment improvements. On the retail side, they are not familiar with, or do not pay much attention to, the multiple dimensions of aquaculture eco-label standards. Thus, they cannot effectively deliver this information to consumers. To the best of our knowledge, no research has been conducted regarding the impact of consumer purchasing behavior on the private and public benefit information of farmed seafood certification. Providing scientific evidence and solutions to these challenges can facilitate both retailers and producers in reaching more sustainable goals for their businesses. They can also provide insights to the Chinese government on ongoing fisheries reform (Cao et al. 2015, 2017).

Another concern is whether or not consumers really care about the ecofriendliness of sustainable seafood (Wessells 2002; Gulbrandsen 2006; Uchida et al. 2014b). There is a consensus that eco-labeled seafood generates a 10-20\% price premium over non-labeled, but it is hard to draw a solid conclusion that consumers are willing to pay for eco-friendliness. In previous studies, consumers are not given full information about the standards of certification or eco-labels, and market data, like retailer scanner data, captures neither consumer's demographic information nor their perceptions about the implications of eco-labels attached to the seafood. It is inappropriate to apply the conclusions of wild seafood studies to farmed seafood because they have different certification standards. Unlike sustainable wild seafood with pure public benefits, such as environmental and community concerns, sustainably farmed seafood standards also consider consumers' private benefits like seafood quality and safety (Roheim, Sudhakaran, and Durham 2012). 
Again, this study applies the experimental auction method and uses sustainably farmed seafood as an example to investigate Chinese consumer WTP for private and public benefit information provided by certification. Inspired by Maslow's Hierarchy of Needs, a similar figure for seafood consumption was created. Figure 3.1 shows that consumers want high-quality seafood and seafood safety, as well as environmental and social contributions. The demand for these attributes is pyramid shaped—physical needs form the base, and psychological needs are located on top. It is of great value to understand how consumers allocate their resources to different attributes of seafood and what factors impact their decisions. Sustainably farmed seafood is a good subject for this study because it covers most of the attributes outlined in the figure.

This study indicates that: 1 . Public benefit information has a significantly high impact on consumers' WTP for certified products, whether domestic or imported, and it is necessary to provide public benefit information prior to private benefit information. 2. There exists preference for certification of imported products over domestic products, which reveals Chinese consumers' lack of trust regarding the credibility of certifiers, as well as their opinions concerning the inability of domestic producers to be compliant. 3. Domestically certified products have a higher response to the information than imported certified products, which is a positive signal for domestic marketers and producers.

The remainder of the chapter proceeds as follows. First, we briefly discuss the background of our study, explain the experimental design, and describe the data collected from experiment. This is followed by the regression models and results. The final section concludes the chapter. 


\section{Background}

Consumer preferences for wild sustainable seafood have been extensively studied for approximately two decades, while little research has been conducted on the farmed seafood sector (Roheim, Sudhakaran, and Durham 2012), particularly in developing countries. Researchers began to study the Chinese sustainable seafood market only a few years ago (Xu et al. 2012). Chinese consumer preferences for seafood are very different from those in Western countries due to unique social norms and the culinary culture, but their tastes are also changing with the times (Fabinyi and Liu 2016). In recent years, Chinese consumer demand for imported seafood has increased rapidly because of frequent outbreaks of domestic food safety incidents (Han and Bi 2016), coupled with fast-growing household income (The World Bank 2016). Chapter 2 states that without safety information or certification, Chinese consumers are willing to pay a premium for imported seafood products; however, for certified domestic products with safety information, consumers tend to pay more. It is certain that Chinese consumers care about seafood safety more than other attributes, but due to the limit of eco-friendly information presented on websites, we could not tell whether or not they are willing to pay a price premium for that public benefit. This is an important area of research for the development of Chinese sustainable aquaculture, because only an accurate description of consumer preferences can help formulate effective marketing strategies.

Seafood producers, especially sustainable seafood producers in China, rely heavily on exports and have very limited price bargaining power in international 
markets. This can potentially cause a downturn for the expansion of sustainable seafood programs in China. The blue swimming crab Fishery Improvement Projects (FIPs) in Indonesia is an example. ${ }^{2}$ Totally relying on Western markets for fishery sustainability improvement is too risky for developing country fisheries. Generating domestic demand for sustainable seafood is an urgent task.

Literature on consumer preferences for sustainable seafood started around 2000, when the first lot of sustainable seafood arrived in the European market. Wessells, Johnston, and Donath (1999) pointed out the importance of consumer knowledge and demand for market-based solutions to fishery sustainability. This paper outlines the impact of safety and quality information on consumer decision-making. This was the first seminal paper in the field and inspired a wide range of research. In early 2000, scholars focused on consumer preferences for eco-labeled wild seafood in North America and Europe. Contingent choice surveys were often used to test factors that influence consumer likelihood of its purchase (Wessells, Johnston, and Donath 1999; Johnston et al. 2001; Jaffry et al. 2004). Researchers unanimously conclude that consumers are willing to pay a price premium for eco-labeled products, but they did not evaluate the quantitative levels of the premium. After 2006 as more and more North American and European retailers started to commit to sustainable seafood, quantitative research was made possible by enriched market data. Roheim, Asche, and Santos (2011) applied scanner data from several London retailers to a hedonic model and found consumers were willing to pay a $14.2 \%$ price premium for MSC-certified

\footnotetext{
${ }^{2}$ Blue swimming crab FIPs in Indonesia were very successful at the beginning. However, they rely heavily on the Western market for sustainability development. When there were not enough economic incentives provided by Western buyers, they chose to degrade their fishing practices and switched to the local market.
} 
seafood in the UK. Bronnmann and Asche (2016) used German market scanner data and found a much lower price premium (4\%) for MSC-certified seafood and a higher premium for farmed seafood (28\%). Besides the Western market, a few studies were also conducted in Japan and China. Onozaka et al. (2010) studied Japanese consumer preferences and acknowledge the positive attitudes of Japanese consumers toward sustainable seafood. Uchida et al. (2014b) confirm this with an auction experiment, finding a statistically significant premium of about $20 \%$ for MSC-labeled salmon over non-labeled when consumers are provided with information on both the status of global fish stocks and the purpose of the MSC program. Xu et al. (2012) found that Chinese consumers are willing to pay a price premium for eco-labeled seafood, and price is not a significant factor affect purchasing decisions. These results show promise for use in creating a sustainable seafood market in China. However, some studies show that very little of the price premium generated by eco-labeling will flow to producers (Stemle, Uchida, and Roheim 2015; Blomquist, Bartolino, and Waldo 2015). Thus, there exists a great challenge to the further development of sustainable fishery programs, especially in developing countries. A local or domestic market could potentially solve this problem, since most eco-labeled seafood is now internationally traded, and the premiums have to be shared by multiple supply chain players. Producers are more likely to be rewarded for their sustainable practices by the support of local/domestic consumers. The first step of creating a domestic market is to have a comprehensive analysis of targeted consumers.

Three research methods are commonly adopted by scholars. The most popular method is contingent choice experiment estimated by a multinomial probit/logit model 
(Wessells, Johnston, and Donath 1999; Johnston et al. 2001; Loureiro, McCluskey, and Mittelhammer 2001; Jaffry et al. 2004; Roheim, Sudhakaran, and Durham 2012; Brécard et al. 2012; Uchida et al. 2014a). The choice experiment is a classic way to elicit consumer preference over a few options when revealed preference data is not available. Using a probit or logit model, it is easy to estimate consumer WTP for a few product attribute of interest. However, high cost and complicated design have limited the wide application of this method in developing countries. Revealed preference data is favored more with the popularization of sustainable seafood products from the retailing ends. Researchers can access retailers' scanner data or online retail data through data service providers or simply online fetching. A hedonic model is useful for the estimation of consumer WTP for various product attributes (Roheim, Asche, and Santos 2011; Asche et al. 2015; Bronnmann and Asche 2016; Wang 2016). The disadvantage of this method is that it cannot incorporate consumer characteristics and test their impact on consumer behavior. According to Lusk's research, consumer perception can significantly affect the interpretation of estimation results (Lusk, Schroeder, and Tonsor 2014). The last method discussed here is experimental auction. Consumer WTP for certain product attributes can be directly elicited from auction results. Information treatments can also be designed into the experiment to test their effectiveness. Further, pre- and post-experiment surveys can be conducted to collect personal information to complement the main experiment as needed (Uchida et al. 2014b; Lusk, Schroeder, and Tonsor 2014). Some other research methods are also found in literature, such as using data from landings tickets and log books (Blomquist, Bartolino, and Waldo 2015), and interview-based analysis (Fabinyi and Liu 2016). 
The method adopted in this study is the experimental auction, with the objective to estimate the treatment effects of private and public benefit information of an aquaculture eco-label on consumers' WTP for sustainably farmed seafood.

\section{Experiment design and data description}

Similar to Chapter 2, white-leg shrimp (Penaeus vannamei) is used again as the representative species. All auctioned products in the experiment were whole, frozen shrimp of the same size to simplify the experiment procedure and data analysis.

A sealed-bid, second-price auction was used, which means the highest price bidder wins the game, but pays the second-highest price. Over the past few decades, several auction methods have been designed to test consumers' WTP, such as the English, Nth price, Becker-Degroot-Marschak (BDM), and random $\mathrm{N}^{\text {th }}$ price auctions. All these methods can be designed into incentive-compatible games, and all have advantages and disadvantages(Lusk 2003) . Based on our research objective, an easyto-understand method that can also receive controlled feedback from participants is desired. A second-price auction is a good option for this study, although there is evidence of subject overbidding (Kagel, Harstad, and Levin 1987; Lusk, Feldkamp, and Schroeder 2004). It is not a serious issue because the bidding difference within subjects is of the major research interest.

A series of experimental auctions was conducted in the spring of 2017 in Xiamen, China, a southeast coastal city with a population of nearly 4 million people. Xiamen is a well-known city in China with a long history of inshore and offshore fisheries. Seafood has always played a vital role in its culinary culture. Due to the collapse of 
wild fish stocks and the rapid increase of market demand, aquaculture has become its main source of seafood in recent years. Thus, it is considered a good place to focus our consumer preference analysis for sustainably farmed seafood in China. Below is a brief introduction of the participant structure and experiment design.

Participants were recruited through social media of a few local organizations and groups. A screening survey was then used to ensure that research subjects were at least 18 years old and regular seafood purchasers. After screening, 78 qualified residents participated in 8 experiment sessions, and 76 effective pre-auction surveys were received. Table 3.1 shows the participant demographics. About $70 \%$ are female, compared to a $51 \%$ female ratio in Xiamen city (Xiamen Statistics Bureau 2017). This is acceptable because food purchasing and cooking is mostly done by females in China. Due to screening, bias is expected on the gender distribution. Our age data ranges from 20 s to 70 s for the participants. We were not able to collect income data, because it is a very sensitive, private question to ask in China, but we gathered occupation data, which can partly represent income. Occupation data show that most of our participants are office workers, in sales, or teachers. This means they are near or at the average income class. Only $17 \%$ are students, and $27 \%$ are housewives or househusbands. In terms of purchasing frequency, $65 \%$ of participants purchase seafood 1-3 times a month. Twenty-two percent purchase once a week, and the rest usually purchase twice a week. Fifty percent of participants purchase seafood at a wet market, which is a Chinese tradition, but these outlets usually lack seafood information. The supermarket share is increasing annually, and it is expected to be the main channel in the future. A few participants buy online or directly from fishmen. 
Survey results also show that consumer understanding of seafood sustainability remains at an extremely low level; $42 \%$ have never heard about it and another $40 \%$ have heard, but did not understand the concept. Only one participant had solid knowledge of sustainable seafood. It is a critical issue, but it also means most participants were at the same knowledge level, which provides a good opportunity to study the impact of information treatments on consumer behavior. Generally, this sample provides a good representation of the population of Xiamen City, as well as southern coastal cities similar to Xiamen.

There are 8 sessions in this experiment and 9-12 participants in each session. All sessions consist of 12 rounds that are evenly divided into 3 blocks by information treatment. Four types of shrimp are used in this experiment: domestic/non-labeled shrimp (DN); domestic/eco-labeled shrimp (DE); imported/non-labeled shrimp (IN); and imported/eco-labeled shrimp (IE). Participants were asked to place their bids under different information scenarios. The auction orders of different product types were altered in each session to balance ordering effects, but the labeled and nonlabeled products were always adjacent to each other for better treatment effects. See Table 3.2 for the design.

In block 1 (rounds 1 to 4), participants were shown pictures of four shrimp products, one at a time (Figure 3.2). ${ }^{3}$ They were then given basic information regarding country of origin and eco-labeling of the products and were asked to submit their bids for each product. For example, in round 1 they were shown a picture of shrimp and told that they were farmed in mainland China and did not have an eco-

\footnotetext{
${ }^{3}$ All pictures are from producers' website. Product sizes were also controlled to minimize bias.
} 
label. Then they were asked, "How much are you willing to pay for 500 grams of this product?"

In block 2 (rounds 5 to 8 ), participants were given additional information about eco-labeling. In sessions $1-4$, private benefit information was given, and in sessions 5-8 public benefit information was provided. Then, participants repeated their activities as in block 1 .

In block 3 (rounds 9 to 12), we gave participants an additional piece of information that was not provided in block 2 . Then, they repeated thee activities as in blocks 1 and 2. Detailed treatment information can be found in Table 3.3. The standards were adopted from "Best Aquaculture Practice Certification Standards, Guidelines" (BAP 2017). So as not to bias participants' valuation, we did not mention which certifying body provided the information.

Each session started by reading the introduction, objectives, and rationale of the research, followed by the optimal bidding strategy. Following Uchida et al.(2014b), the bidding strategy was explained and demonstrated. This could potentially lead to slightly higher average bids than those using other methods (Lusk et al. 2004), but this bias should appear equally across treatments. A practice round was played for candy bars to familiarize participants with the auction mechanism. For incentive compatibility, after 12 rounds of bidding we used a lottery system to decide one winner for real purchase. All participants received 150 yuan (about US \$25) of compensation, except for the winners. The winners had to purchase the product of the winning round at the second highest price using part of their compensation and received the rest of the money. Since it is impractical and unhygienic to award actual 
shrimp products, prizes were delivered from online retailers to the winners' homes directly.

\section{Data description}

Panel data using 78 individuals and 12 time-period rounds resulted in 936 sample points. The dependent variable is the bid placed by individuals in each round, and dependent variables are product forms and information treatments. See Table 3.4 for the summary statistics of the main variables. The average bidding for all products is around 35 yuan (about US \$6), which is close to the true market value for 500 grams of shrimp in China. Product types and information treatments are all dummy variables. All four product types are evenly tested throughout the experiment. For information treatments, basic information was given in sessions 1-8; private and private + public benefit information was given in sessions $1-4$; public and public + private benefit information was given in sessions 5-8. The sample sizes are nearly identical for the two parts.

Tables 3.5-3.8 display the treatment effects. First, all bidding is separated into two groups of country of origin and eco-labeling to evaluate consumers' average WTP for each category and test whether or not there is a price premium for imported products and eco-labeled products. As shown in Table 3.5, columns 1, 2, 5, and 6 list the means and standard deviations of each category. Columns 3 and 7 show the differences of imported versus domestic products and eco-labeled versus non-labeled products. Columns 4 and 8 display the t-values of the differences tested using a paired t-test at the $95 \%$ confidence interval. All bidding is also categorized by information 
treatments from basic to full information. This table is not difficult to interpret. In row 1, when given only basic information, consumers are willing to pay 29.83 and 36.36 yuan, on average, for domestic and imported shrimp, respectively. There exists a significant premium of 6.54 yuan for imported over domestic shrimp. This signifies that the difference is not caused by a few extremely high bids, but an average high bid for imported shrimp across all participants. Reading this table as a whole, we find more interesting results. Comparing column 3 to column 7, with only basic information consumers are willing to pay more than $20 \%$ for imported and eco-labeled products. Providing private benefit information of sustainable certification increases consumer WTP for both domestic and imported products, but does not generate a premium for imported products. Further, providing public benefit information generates a premium for imported products. This means Chinese consumers view domestic and foreign producers as identical for providing private benefits, while they are willing to pay more for foreign producers to provide public benefit services. In other words, they do not trust domestic producers who provide public services. For eco-labels, consumers also act positively when public benefit information is provided, which means they still view sustainable aquaculture eco-labels as a public-service provider only, even when they were informed of private benefit information. It is not feasible to conduct a vertical comparison, since no tests have been conducted across information treatments and the sample sizes are not equal.

Table 3.6 compares the bidding from information treatment groups against the basic information group (the control group is omitted in the table). Again, we group all bidding into four basic categories. Except for the non-labeled category, the remaining 
categories show positive, significant premiums in the "public then private benefit information" treatment. This is because all three categories have an eco-labeled attribute involved, which is very effective in generating consumer WTP upon public benefit information provision according to the results from Table 3.5. For the nonlabeled category, private benefit information does a better job than public benefit information. Since non-labeled products do not provide any private benefits from certification, this premium could only come from the imported section of the nonlabeled products, and consumers might believe that imported products could also provide some private benefits even without certification, but not public benefits. No significant sequential effect was shown in the domestic category. While in the imported and eco-labeled categories, "public then private benefit" information has a greater impact than "private then public benefit" information.

Since the categories in Tables 3.5 and 3.6 are not mutually exclusive, we can only have a basic understanding of the information impacts, and it is difficult to completely interpret some of the outcomes. Here we take it one step further, dividing all bidding into four mutually exclusive categories: domestic/and non-labeled (DN), domestic/eco-labeled (DE), imported/non-labeled (IN), and imported/eco-labeled (IE). Table 3.7 illustrates the interactive effects of country of origin and the eco-label. Results show that consumers are willing to pay more for an eco-label on domestic products than the same label on imported products when public benefit information is provided. This may indicate Chinese consumer lack of trust with the domestic producers' level of compliance and certifiers' credibility. Private benefit information 
does not have a significant impact on consumers' WTP for both domestic and imported eco-labels.

Table 3.8 is similar to Table 3.6, but with more detailed categorization. As expected, whether the product is domestic or imported, non-labeled products show no positive response to public benefit information, but both domestic eco-labeled and imported eco-labeled products receive a high premium for public benefit information. In particular, a combination of public then private benefit information creates the highest premium. Recalling the results from Table 3.7, Chinese consumers generally prefer an eco-label on imported products. Surprisingly, however, we find that all information treatments have a higher premium for domestic eco-labeled products than imported eco-labeled products. It is not controversial to the previous results because this is a vertical comparison, which emphasizes the positive impact of public benefit information to domestic eco-labeled products.

A few conclusions can be drawn from the above tables. Public benefit information has a significant impact on consumer WTP for certified products, whether domestic or imported, and it is necessary to provide public benefit information prior to private benefit information.

There exists a preference for certification of imported products over domestic products, which reveals Chinese consumers' lack of trust of certifiers' credibility in China, as well as the level of compliance of domestic producers.

Domestically certified products have a higher response to detailed certification information than imported certified products, which is a positive signal for domestic marketers and producers. 


\section{Regression and prediction}

The tables, above, provide a general understanding of how Chinese consumers view certification information on sustainably farmed seafood. To generate more reliable estimations and be able to make predications, a regression model is needed. A hedonic model is adopted for this analysis.

Because this is a multiple-participant, multiple-round experiment, the bidding is panel data. Unobserved heterogeneity of participants can be eliminated through the within effects. The dependent variable here is the bidding price, which is consumers' WTP. Independent variables are product attributes, information treatments and interaction terms. Below is the model specification:

$$
\begin{gathered}
B_{i t}=\beta_{0}+\sum_{n=1}^{3} \beta_{1 n} \text { Product }_{n}+\sum_{k=1}^{4} \beta_{2 k} \text { Info }_{k}+\sum_{t=2}^{12} \beta_{3 t} \text { Round }_{t} \\
+\sum_{n=1}^{3} \sum_{k=1}^{4} \gamma_{n k} \text { Product }_{n} * \text { Info }_{k}+\varepsilon_{i t}
\end{gathered}
$$

In this model, the dependent variable, $B_{i t}$, is the bid from individual $i$ in round $t$. $\beta_{0}$ is the constant term. Certification, Import, and Info are all binary dummy variables. There are four information dummies that cover five treatments: basic information, private benefit information, public benefit information, private + public benefit information, and public + private benefit information. The time variable, Round $_{t}$, is controlled for a learning effect through the experiment. Information variables are also interacted with import and certification variables. $\varepsilon_{i t}$ is the observation-specific error term. 
A hedonic price model provides confirmation of our previous outcomes from average treatment effects and predicts the outcome based on information. A Hausman test was conducted to evaluate the fixed and random effects, and results suggest a random effects regression was more appropriate for this model. See Table 3.9 for the coefficient estimates.

Two models are displayed in Table 3.9, one without interaction terms and one with them. The interaction terms between product attributes and information treatments have improved the explanatory power of the model and provided more insightful implications for the study. Predictions were made using Model 2, and Table 3.10 was created to interpret their value.

Results in Table 3.10 are very similar to Table 3.8, which once again reinforces the effectiveness of our regression model. Table 3.10 shows that for the DN product, only private benefit information and private + public benefit information treatments indicate significant differences from basic information. For the IN product, providing private benefit information generated some negative effects. This is reasonable, since there is no such benefit involved in this type of product. But for the DE and IE products, public benefit information generated positive, large numbers of premiums. Once again, providing public benefit first made a difference. Basically, the same conclusion can be made here as in the previous section.

\section{Conclusion and discussion}

Sustainable seafood programs are not a perfect system that could solve every fishery management issue immediately, but there is no doubt this is one of the most important 
mechanisms to slow down the degradation of wild fishery stocks and improve coastal fishery communities. Sustainable seafood programs have evolved for about two decades as a market-based mechanism and have successfully incentivized fishmen/fish farmers globally to produce in a more sustainable manner. At the same time, industry and academia have never stopped doubting program designs and actual environmental impacts. Thus, when promoting these programs, especially in developing nations, we need to carefully study local markets and government situations.

Historically, seafood has been a luxury product in China, and not until recently has it become an everyday food for most consumers. As household incomes continue to increase, average seafood consumption is predicted to reach $50 \mathrm{~kg} /$ year/capita. Since China has the world's largest population, it will consume a significant amount of fish every year. Sustainable fisheries and aquaculture are the only ways for China to maintain healthy wild fish stocks and ocean environment without damaging global fisheries resources. Currently, neither China's seafood industry nor general public has a thorough understanding of sustainable seafood, especially sustainable aquaculture. Urgent tasks include public education to raise consumer awareness, as well as modify current sustainable seafood programs to fit into Chinese consumers' everyday life. This may be accomplished through the study of their preferences.

In this chapter, Chinese consumer preferences for sustainably farmed seafood were studied using a sealed-bid, second-price experimental auction method. This is an incentive-compatible experiment design aiming to elicit consumers' true WTP. Conclusions can be drawn as follows. 
1. Chinese consumers believe that domestic products can provide better private benefits than imported products even without a certification, but they are willing to pay more for certification on imported products than domestic products, which means they have less trust in domestic producers.

2. Chinese consumers are willing to pay a premium for eco-labeled products, especially when public benefit information is provided. Consumers can verify private benefits simply through consumption, but they need certification to verify public benefits on both products, since public benefits are credence attributes that are difficult to evaluate through consumption. That is why public benefit information generates a premium on eco-labeled products, but this is not the case for private benefit information. Consumers still consider sustainable aquaculture certification as a pure public benefit. Providing public benefit information can significantly increase consumers' WTP for eco-labeled products.

3. There exists a different marketing strategy for each type of product. For both domestic and imported eco-labeled products, it is best to provide public and then private benefit information, while for imported, non-labeled products, providing private benefit information first then public benefit information will generate better results. For domestic, non-labeled products, our results show private benefit information will increase the consumers' WTP. This is a debatable result, however, since it is not reasonable for consumers to pay more for non-labeled products when certification information is provided.

This research has resulted in some recommendations for both Chinese retailers and government. However, the research scope is limited to downtown Xiamen City, 
which cannot represent the general public in China. Thus, retailers need to test the preferences of consumers within their service range and decide what types of seafood will generate the highest profit. For some retailers, even though sustainable seafood is not the best option to maximize profit currently, it may be beneficial to consider corporate social responsibility and the positive benefits generated by good business practices and a strong reputation. Once the main products are determined, the types of information consumers value and may be willing to pay more for, need to be determined. Results from this study can be a good reference for creating corporate marketing strategies. For the Chinese government, it is vital to rebuild consumer confidence regarding domestic farmed seafood products. Historically, Chinese consumers have preferred local seafood and agricultural products for both quality and emotional reasons. However, they switched to imported products due to seriously degraded product quality and safety concerns. Building a credible domestic certification system that covers both private and public benefits is an urgent task at hand. Last year Chinese authorities started to reform fisheries and the seafood industry to ensure product quality and safety. The next step is to focus on policy enforcement and supervision.

In the next chapter, the experimental data is used again, but consumer perceptions of the quality, safety, and eco-friendliness of sustainably farmed seafood will be added to the analysis in order to test their WTP for these attributes. 
Figure 3.1. An Application of Maslow's Hierarchy of Needs to Seafood

Self-actualization:

responsible

seafood

Esteem needs:

sustainable seafood

Belongingness and love

needs:

product origin of seafood

Safety needs:

seafood security, safety

\section{Physiological needs:}

seafood quality 
Table 3.1. Distribution of Participant Demographics

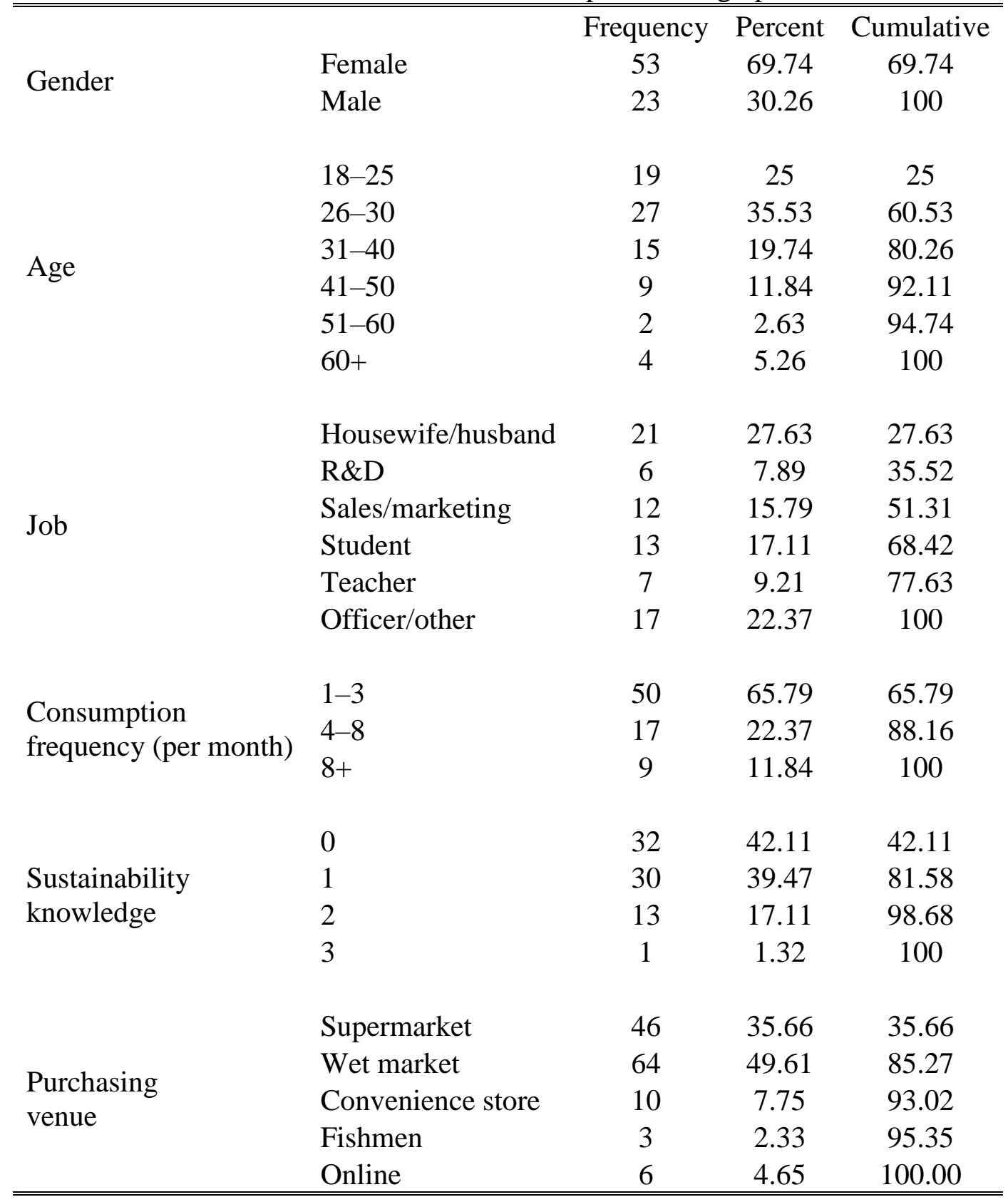




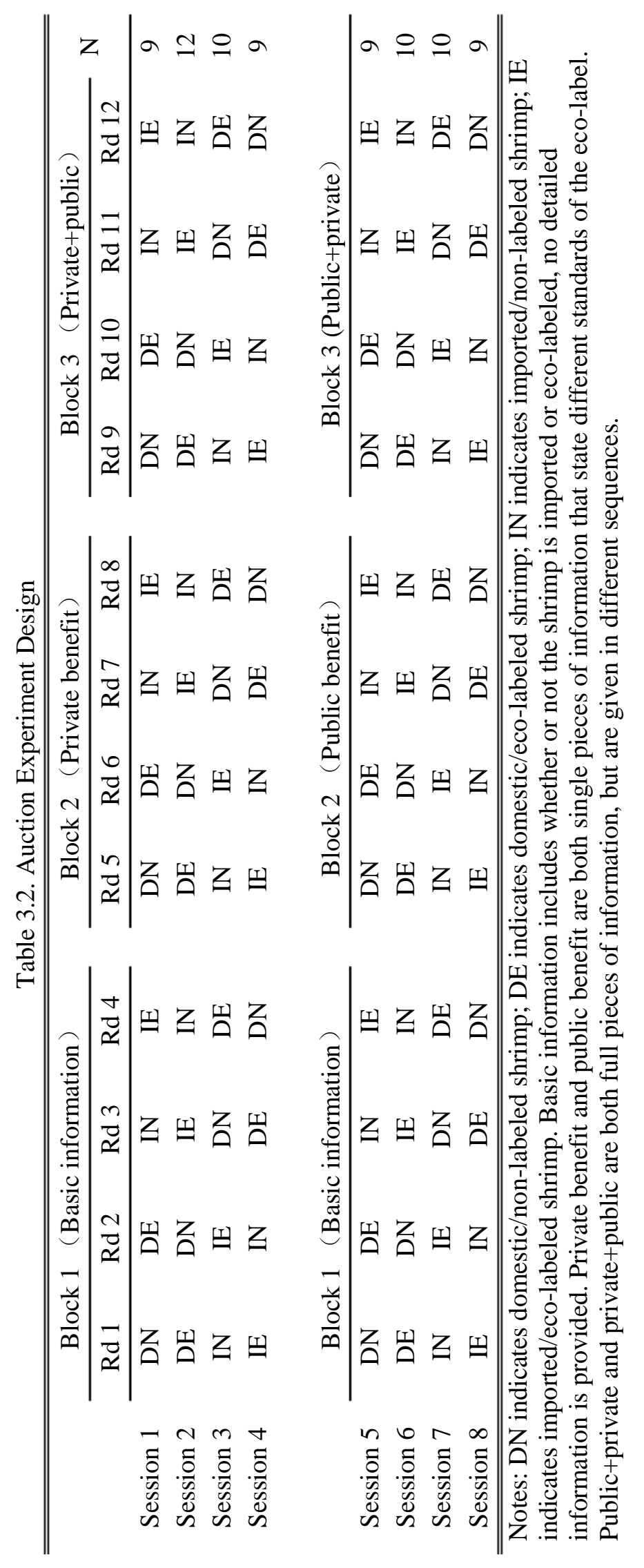


Figure 3.2. Display Photos Used in the Experiment
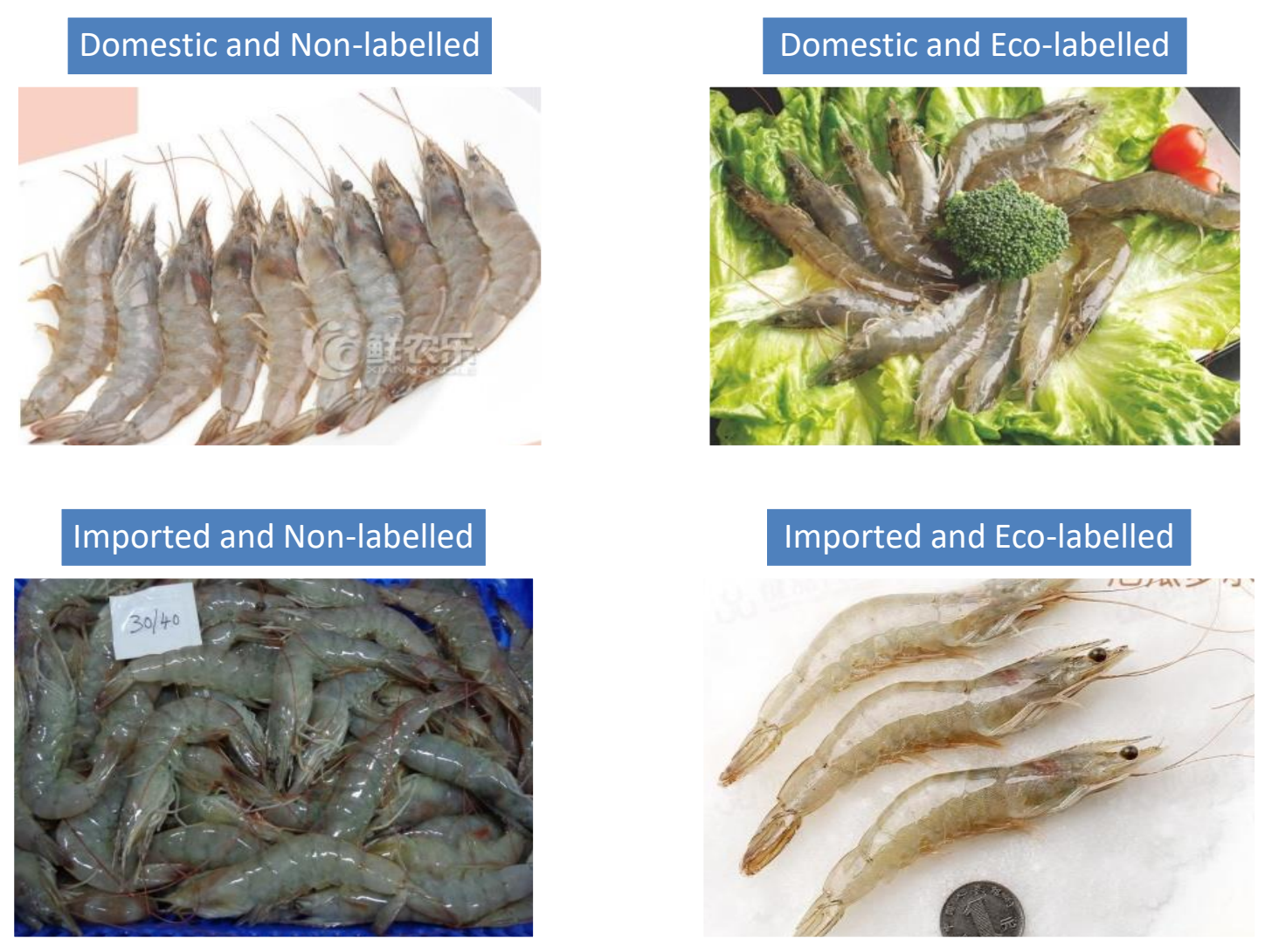
Table 3.3. Public and Private Benefit Information

1 Mangrove and Wetland Conservation: Aquaculture facilities shall not be located in a mangrove or other wetland areas where they displace important natural habitats. Farm operations shall not damage wetlands, except for allowable purposes, which shall be mitigated.

2 Effluent Management: Aquaculture facilities shall monitor their effluents to confirm compliance with the BAP effluent water quality criteria defined in Appendix A. Water quality measurements taken during the audit shall meet both BAP criteria and those of applicable government permits. Facilities shall comply with BAP's final criteria within five years. Water exchange shall be limited to reduce overall environmental impacts.

3 Soil and Water Conservation, Pond Sludge Management: Farm construction and operations shall not cause soil and water salinization or deplete groundwater in surrounding areas. Farms shall properly manage and dispose of sediment from ponds, raceways, canals, and settling basins.

Public benefit information
4 Fishmeal and Fish Oil Conservation: Farms shall accurately monitor feed inputs and minimize the use of fishmeal and fish oil derived from wild fisheries

5 Stocking Sources and GMOs: Wild juveniles shall not be stocked. Certified farms shall comply with governmental regulations regarding the use of native and non-native species and genetically modified aquaculture species.

6 Biodiversity and Wildlife Protection: Certified farms shall manage physical interactions with wildlife.

7 Storage and Disposal of Farm Supplies and Waste: Fuel, lubricants and agricultural chemicals shall be stored and disposed of in a safe and responsible manner. Paper and plastic refuse shall be disposed of in a prompt, sanitary, and responsible way. Excessive accumulation of waste and/or discarded farm supplies and equipment shall be removed and disposed of responsibly.

8 Animal Health and Welfare: Producers shall demonstrate that all operations on farms are designed and operated with animal welfare in mind, and maximum survival shall be sought. Employees shall be trained to provide appropriate levels of husbandry. 
Table 3.3. Public and Private Benefit Information (continued)

1 Chemical and Drug Management: Proactively prohibited antibiotics, drugs, and other chemical compounds shall not be used. Other therapeutic agents shall be used as directed on product labels for control of diagnosed diseases or required pond management, and not for prophylactic purposes without veterinary oversight.

2 Microbial Sanitation, Hygiene: Human waste and untreated animal manure shall be prevented from contaminating pond waters. Domestic sewage shall be treated and not contaminate surrounding areas.

3 Disease Control: Biosecurity controls shall be in place to prevent the introduction and/or spread of disease agents and disease on the farm. These include regular disease surveillance, sanitation of equipment and personnel, quarantine of diseased animals, and controlled movement of personnel and equipment. Farm staff and visitors shall be trained in and apply biosecurity measures.

Private benefit information
4 Harvest and Transport: Aquacultured products shall be harvested and transported to processing plants or other markets in a manner that maintains temperature control and prevents physical damage or contamination. Sulphites shall be handled responsibly to control risks to consumers and the environment.

5 Traceability: To establish product traceability, the following data shall be recorded for each culture unit and each production cycle: Culture unit identification number

Unit area or volume

Stocking date

Quantity of fingerlings or postlarvae stocked

Source of fingerlings or postlarvae (hatchery)

Antibiotic and drug use

Sulfite use in shrimp

Herbicide, algaecide, and other pesticide use Manufacturer and lot number for each feed used Harvest date and quantity Movement document number (if applicable) Processing plant(s) or purchaser(s) (Identify all if any harvest quantity goes to more than one plant or purchaser) 
Table 3.4. Summary Statistics of the Main Variables

\begin{tabular}{lcllll}
\hline \hline Variable & Obs. & Mean & Std. Dev. & Min. & Max. \\
& & & & & \\
Bid & 936 & 34.93536 & 19.74875 & 0 & 200 \\
& & & & & \\
Domestic/non-labeled & 936 & 0.25 & 0.433244 & 0 & 1 \\
Domestic/eco-labeled & 936 & 0.25 & 0.433244 & 0 & 1 \\
Imported/non-labeled & 936 & 0.25 & 0.433244 & 0 & 1 \\
Imported/eco-labeled & 936 & 0.25 & 0.433244 & 0 & 1 \\
& & & & & \\
Basic information & 936 & 0.333333 & 0.471657 & 0 & 1 \\
Private benefit information & 936 & 0.17094 & 0.376658 & 0 & 1 \\
Public benefit information & 936 & 0.162393 & 0.369008 & 0 & 1 \\
Private+public benefit info. & 936 & 0.17094 & 0.376658 & 0 & 1 \\
Public+private benefit info. & 936 & 0.162393 & 0.369008 & 0 & 1 \\
\hline \hline
\end{tabular}




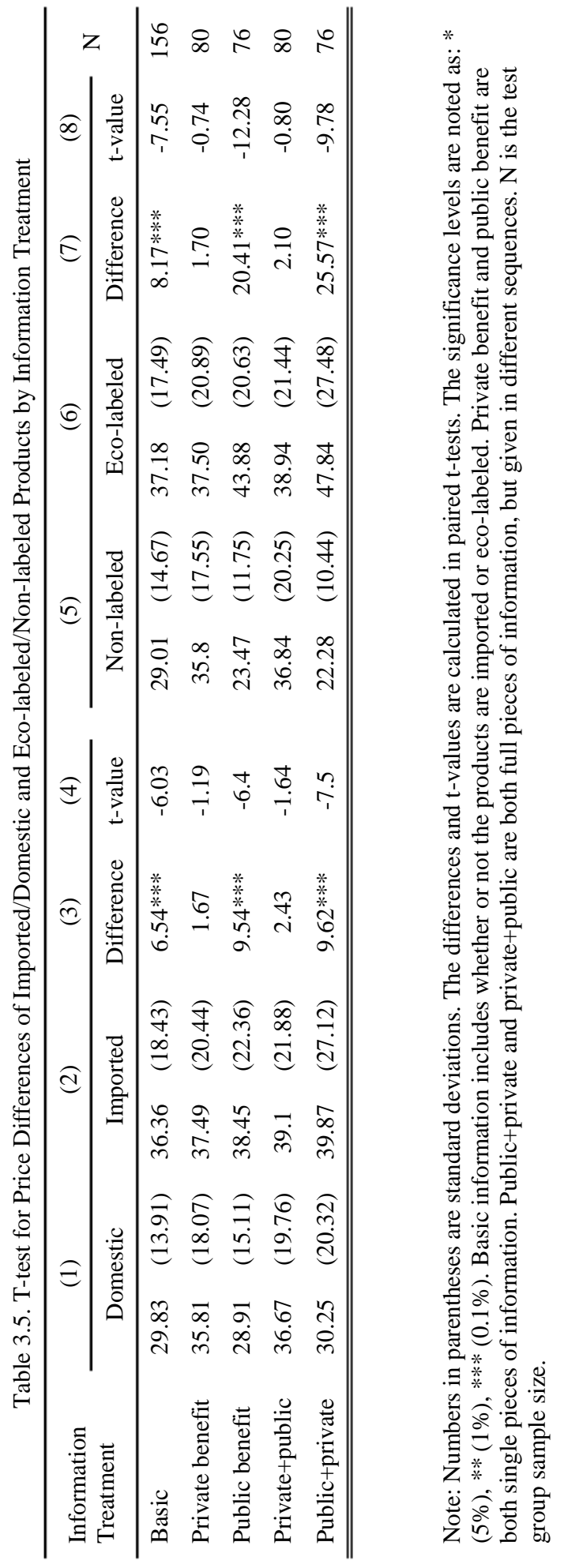




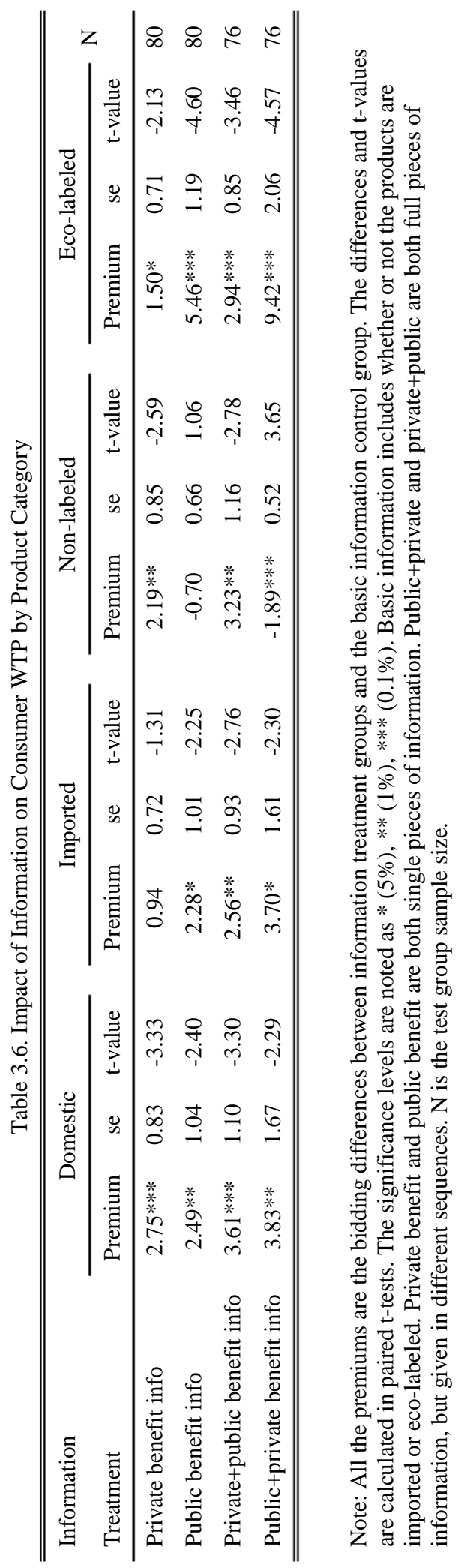




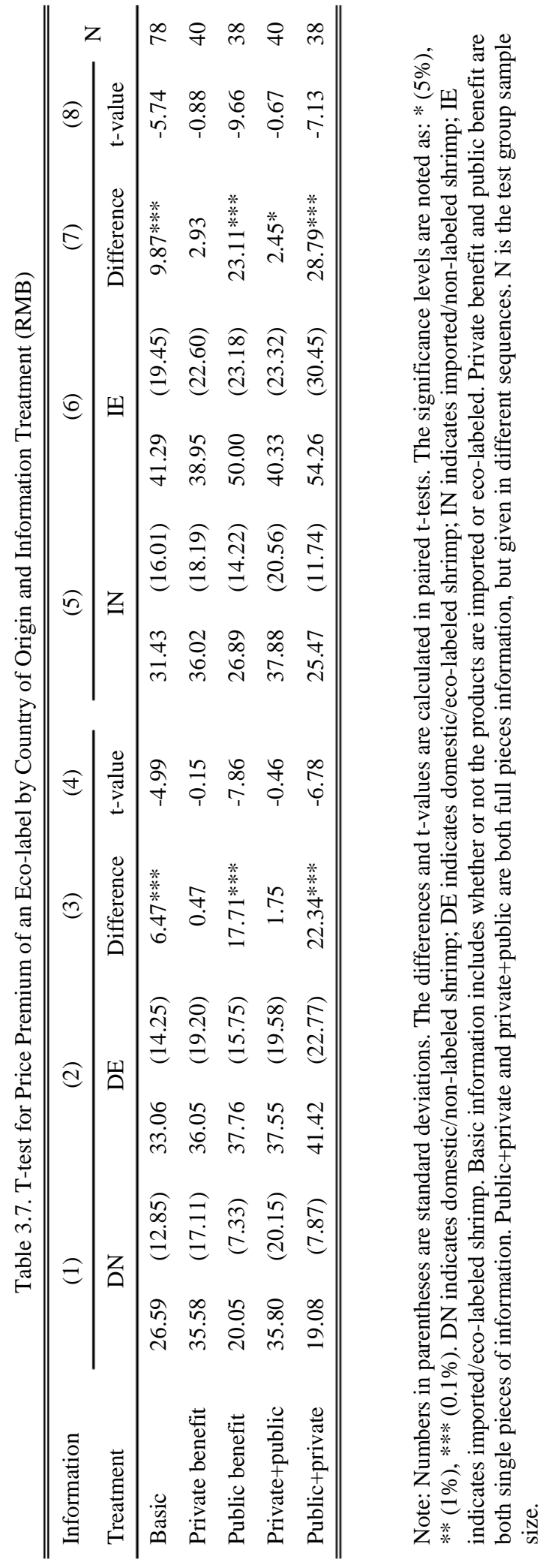




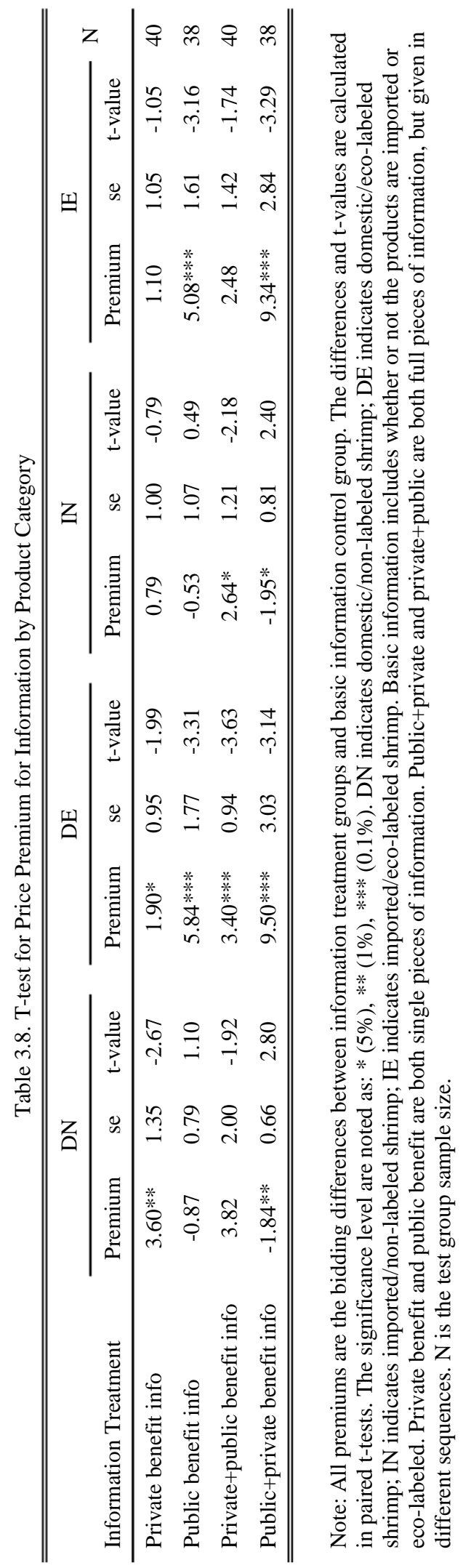


Table 3.9. Coefficient Estimates

\begin{tabular}{|c|c|c|}
\hline \multirow{2}{*}{ Variable } & \multicolumn{2}{|c|}{ Bidding (RMB: yuan) } \\
\hline & $(1)$ & $(2)$ \\
\hline Constant & $\begin{array}{c}20.788 * * * \\
(2.232)\end{array}$ & $\begin{array}{c}20.788 * * * \\
(2.232)\end{array}$ \\
\hline Domestic \& eco-labeled (DE, yes $=1$, otherwise $=0)$ & $\begin{array}{c}9.239 * * * \\
(1.073)\end{array}$ & $\begin{array}{c}6.593 * * * \\
(1.694)\end{array}$ \\
\hline Imported \& non-labeled (IN, yes $=1$, otherwise $=0$ ) & $\begin{array}{c}4.009 * * * \\
(1.073)\end{array}$ & $\begin{array}{c}4.637 * * * \\
(1.694)\end{array}$ \\
\hline Imported \& eco-labeled (IE, yes=1, otherwise $=0)$ & $\begin{array}{c}16.966 * * * \\
(1.071)\end{array}$ & $\begin{array}{c}14.763^{* * * *} \\
(1.692)\end{array}$ \\
\hline Only private benefit info $($ yes $=1$, otherwise $=0$ ) & $\begin{array}{c}16.044 * * * \\
(2.048)\end{array}$ & $\begin{array}{c}21.243 * * * \\
(2.608)\end{array}$ \\
\hline Only public benefit info (yes $=1$, otherwise $=0$ ) & $\begin{array}{c}16.045 * * * \\
(2.068)\end{array}$ & $\begin{array}{c}8.883 * * * \\
(2.634)\end{array}$ \\
\hline Private then public benefit info $($ yes $=1$, otherwise $=0$ ) & $\begin{array}{c}17.884 * * * \\
(2.048)\end{array}$ & $\begin{array}{c}21.971 * * * \\
(2.608)\end{array}$ \\
\hline Public then private benefit info $($ yes $=1$, otherwise $=0$ ) & $\begin{array}{c}18.029 * * * \\
(2.068)\end{array}$ & $\begin{array}{c}8.490 * * * \\
(2.634)\end{array}$ \\
\hline $\mathrm{DE} *$ private benefit info & & $\begin{array}{c}-5.690 * \\
(2.909)\end{array}$ \\
\hline IN $*$ private benefit info & & $\begin{array}{l}-4.522 \\
(2.909)\end{array}$ \\
\hline IE $*$ private benefit info & & $\begin{array}{c}-11.136 * * * \\
(2.906)\end{array}$ \\
\hline $\mathrm{DE} *$ public benefit info & & $\begin{array}{c}11.075^{* * *} * \\
(2.957)\end{array}$ \\
\hline IN $*$ public benefit info & & $\begin{array}{c}2.163 \\
(2.957)\end{array}$ \\
\hline IE* public benefit info & & $\begin{array}{c}15.184 * * * \\
(2.955)\end{array}$ \\
\hline $\mathrm{DE} *$ Private then public benefit info & & $\begin{array}{l}-4.299 \\
(2.909)\end{array}$ \\
\hline IN $*$ Private then public benefit info & & $\begin{array}{l}-2.844 \\
(2.909)\end{array}$ \\
\hline IE $*$ Private then public benefit info & & $\begin{array}{c}-9.836 * * * \\
(2.906)\end{array}$ \\
\hline $\mathrm{DE} *$ Public then private benefit info & & $\begin{array}{c}15.712 * * * \\
(2.957)\end{array}$ \\
\hline IN* Public then private benefit info & & $\begin{array}{c}1.721 \\
(2.957) \\
\end{array}$ \\
\hline
\end{tabular}


Table 3.9. Coefficient Estimates (continued)

IE* Public then private benefit info 20.421***

(2.955)

Observations

933

933

Number of id

78

78

Wald chi-square statistics

308.29

498.94

Standard errors in parentheses. $* * * \mathrm{p}<0.01, * * \mathrm{p}<0.05, * \mathrm{p}<0.1$ 


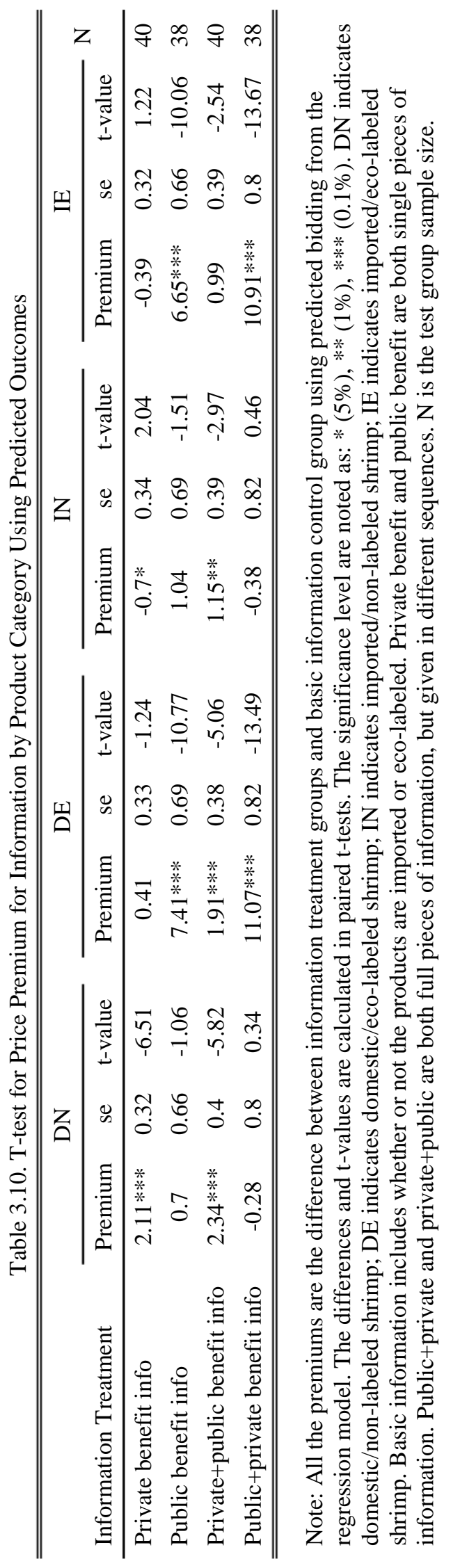




\section{CHAPTER 4}

\section{ESTIMATION OF CHINESE CONSUMER WILLINGNESS TO PAY FOR THE QUALITY, SAFETY AND ECO-FRIENDLINESS OF SUSTAINABLY FARMED SEAFOOD}

\section{Introduction}

In the previous chapters, we discussed the impact of information on the price for sustainably farmed seafood. Regardless if market data or experiment data were used, we were only able to evaluate explicitly revealed seafood attributes, such as country of origin and certification, and were unsure to what extent consumers understood the information and how they used it for decision making. Lusk and his colleagues conducted two non-hypothetical choice experiments and one non-hypothetical experimental auction to demonstrate the importance of incorporating consumers' subjective perceptions when testing their food preferences (Lusk and Schroeder 2004; Lusk, Feldkamp, and Schroeder 2004; Lusk, Schroeder, and Tonsor 2014). Usually food attributes are a mixture of basic elements; thus, it is not easy to evaluate them directly. For example the "imported" attribute might be a representation of both quality and safety for Chinese consumers, and the "eco-label" attribute could be a mixture of quality, safety, and eco-friendliness. Previously, we estimated the value of “imported" and "eco-label" attributes, but could not evaluate consumers' WTP for quality, safety, and eco-friendliness because they were not expressed explicitly. In this chapter, we assume that product quality, safety, and eco-friendliness are three basic 
components of consumers' utility function. Product quality and safety have always been primary attributes in consumer preference studies (Zeithaml 1988; Grunert 2002; Fonner and Sylvia 2015; Han and Bi 2016). Credence attributes, like eco-friendliness, pique researchers' interest, as consumer awareness has steadily increased over the past decade (Brécard et al. 2012; Xu et al. 2012; Sogn-Grundvåg, Larsen, and Young 2014; Blomquist, Bartolino, and Waldo 2015). Other factors that might affect consumer preferences, such as workers' welfare, gender equality, and animal welfare, are not considered explicitly in this research. Only with a deeper understanding of consumer preferences of these basic elements could we develop more efficient and effective marketing strategies to capture the optimal value for sustainably farmed seafood.

Following previous experimental auctions, we asked participants to report their perceptions of product quality, safety, and eco-friendliness at the end of each round. A panel data set was constructed through the multiple-round experiment. Using a random-effects GLS regression model, regression results found out that for 500 grams of medium-size frozen raw white-leg shrimp, consumers with a mixed level of information generally were willing to pay 30.54 yuan for guaranteed good quality, 19.84 yuan for guaranteed health safety, 12.16 yuan for eco-friendliness, and 3.53 yuan for other guaranteed attributes. Taking the information treatments into consideration, with only basic information consumers tend to pay more for guaranteed quality. Once they received private and public benefit information, they reallocated a portion of payment from quality to safety and eco-friendliness, increasing their total WTP. Results from this study could be used as marketing strategies for sustainable 
seafood, as well as government policy making. The remainder of this chapter is arranged as following. In next section, we discuss the data acquired from the previous experiment. After that, the model specification and estimation results are reported. Finally, conclusions are presented.

\section{Data description}

Consumer perception data and bidding information were collected in the experiment. The procedure is identical to the auctions in Chapter 3. The questions are: "To what extent (_ $\%$ ) do you believe that this product is of $100 \%$ quality/safety/ecofriendliness?" Here, no specific explanation or definition of the quality, safety, and eco-friendliness was provided. Instead, a few examples were given to guide them while building their evaluation system based on their knowledge and consumption experiences. For instance, participants were told that quality indicators could be seafood freshness, taste, or presentation; indicators of safety could be the level of antibiotic use or heavy metal residues; indicators for eco-friendliness could be the impact on coastal wetlands or the use of fishmeal that contains wild fish. Thus, the questions were reformed as: "To what extent do you believe that this shrimp is fresh enough to make you 100\% satisfied?" "To what extent do you believe that the heavy metal level within this shrimp makes you not to worry about the negative health impact by consuming it?" "To what extent do you believe that farming this shrimp will not cause damage the wetland in its surroundings?"

Recalling the research design in Chapter 3, 8 sessions of sealed-bid, second-price auctions were conducted, with 12 rounds in each session. To enlarge the sample size 
and gain better estimation results, three additional sessions, conducted in Beijing, were added to the data set. Due to time constraints, only three of eight sessions were finished as planned, but the additional data were very helpful for our analysis. The three sessions doubled our observations for the basic information, private benefit information, and private + public benefit information treatment groups. A session started round 1 with basic information on country of origin and certification, then added different information to participants every four rounds. During sessions 1 to 4, basic information appeared from rounds 1 to round 4 . Then private benefit information was then provided from rounds 5 to 9 , and public benefit information was added in the last four rounds. In sessions 5 to 8 the experiment followed the same logic, but reversed the order of private benefit information and public benefit information. Beijing sessions are number sessions 9, 10, and 11, which are repetitions of session 1 , 2, and 3. Participant perceptions of quality, safety, and eco-friendliness for each round were collected after bidding was complete. Table 4.1 shows the summary statistics of consumer bids and perceptions of product quality, safety, and eco-friendliness. In general people have similar perceptions about seafood quality and safety, but a slightly lower confidence in eco-friendliness. The average bid of these 11 sessions is about 38 yuan, and consumers believe that seafood in the market have only $65 \%$ chance to satisfy them in quality and safety, only $50 \%$ chance to be eco-friendly. In addition to Table 4.1, Figure 4.1 summarizes consumer bids and perceptions of product quality, safety, and eco-friendliness by product type and information treatment. This summary indicates that for all four types of products, consumers have similar perceptions about quality and safety, both of which are much higher than their perception of eco- 
friendliness. This is expected, as seafood eco-friendliness is a new concept in China that has not been acknowledged and accepted by general public. For information treatment effects, consumers should reevaluate their perceptions of non-labeled products if they receive additional certification information; for eco-labeled products, private benefit information is likely to increase their perceptions of quality and safety, and public benefit information should increase their perception in eco-friendliness. Figure 4.1 shows that for both domestic/non-labeled and imported/non-labeled products, providing public benefit information has a negative impact on perceptions for all three factors, but providing private benefit information can increase consumer perceptions. For eco-labeled products, private benefit information has no positive impact, but public benefit information increases consumers' perceptions in all three areas. For all products, it is the first piece of information that matters most, as the second piece does not add too much to consumer opinion. Figure 4.1 also shows that consumers' bids are correlated with their perceptions, which confirms the original hypothesis. The next step is to calculate consumers' WTP for quality, safety, and ecofriendliness.

\section{Model specification and estimation}

Following Lusk, Schroeder, and Tonsor (2014), a random expected utility model is used to evaluate consumers' expected utility for different types of farmed seafood products:

$$
E U_{i k}=\sum_{j=1}^{J} p_{i k}^{x_{j}} U\left(x_{j}\right)+\alpha y+\gamma_{k} .
$$


$E U_{i k}$ is the expected utility of individual $i$ for product $k$, where $k$ is one of the four types of seafood: domestic/non-labeled (DN), domestic/eco-labeled (DE), imported/non-labeled (IN), and imported/eco-labeled (IE). DN is used as the basic group.

$p_{i k}^{x_{j}}$ is the perception of individual $i$ for attribute $x_{j}$ of product $k$, where $x_{j}$ can be quality, safety, or eco-friendliness. $U\left(x_{j}\right)$ is the the utility of attribute $x_{j}, y$ is the income variable, and $\alpha$ is the marginal utility of income. $\gamma_{k}$ is the subject invariant constant for product $k$. For example, $\gamma_{I E}$ is the utility that the consumer gains from imported/eco-labeled seafood not accounted for by attribute quality, safety, or ecofriendliness. From equation (1), two utility functions of DN and DE are formed as follows:

$$
\begin{gathered}
E U_{i D N}=p_{i D N}^{q u a l i t y} U(\text { quality })+p_{i D N}^{\text {safety }} U(\text { safety })+p_{i D N}^{\text {eco }} U(\text { eco })+\alpha y+\gamma_{D N} \\
E U_{i D E}=p_{i D E}^{\text {quality }} U(\text { quality })+p_{i D E}^{\text {safety }} U(\text { safety })+p_{i D E}^{\text {eco }} U(\text { eco })+\alpha y+\gamma_{D E} .
\end{gathered}
$$

Suppose consumer $i$ is willing to pay $\Delta W T P_{i D E \rightarrow D N}$ to switch from DN to DE, then the equation to connect the two functions above is:

$$
E U_{i D E}=E U_{i D N}+\alpha \Delta W T P_{i D E \rightarrow D N}
$$

Substituting equations (2) and (3) into (4) and rearranging gives the final regression model:

$$
\begin{aligned}
\Delta W T P_{i D N \rightarrow k}= & \frac{U(\text { quality })}{\alpha} \Delta p_{i D N \rightarrow k}^{\text {quality }}+\frac{U(\text { safety })}{\alpha} \Delta p_{i D N \rightarrow k}^{\text {safety }}+\frac{U(\text { eco })}{\alpha} \Delta p_{i D N \rightarrow k}^{\text {eco }} \\
& +\frac{\Delta \gamma_{D N \rightarrow k}}{\alpha}
\end{aligned}
$$


$K$ is either product DE, IN, or IE. $\Delta W T P_{i D N \rightarrow k}$ is the bid difference of individual $i$ between product $\mathrm{DN}$ and product $\mathrm{k}$ from the auction. $\Delta p_{i D N \rightarrow k}^{q u a l i t y}$ is the difference of quality perception of individual i between product DN and k. $\Delta p_{i k \rightarrow D N}^{\text {safety }}$ is the difference of safety perception of individual i between product DN and k. $\Delta p_{i D N \rightarrow k}^{e c o}$ is the difference of the eco-friendliness perception of individual i between product DN and $\mathrm{k}$. The coefficients of $\frac{U(\text { quality) }}{\alpha}, \frac{U(\text { safety) }}{\alpha}, \frac{U(\text { eco })}{\alpha}$, and $\frac{\left(\gamma_{k}-\gamma_{D N}\right)}{\alpha}$ are the marginal utilities of income; namely, the WTP for quality, safety, eco-friendliness, and other attributes not accounted for by the previous three.

The original data were reformed into new panel data according to the structure of the regression model. For each individual, their bids and perceptions of DE, IN, and IE products are deducted by those of the DN products. A random-effects panel data regression was suggested by Hausman test to estimate the coefficients.

\section{Estimation results}

Table 4.2 summarizes six different regressions by information treatment. In Column (1), all data were pooled by consumer preferences with mixed levels of information. Results suggest that for 500 grams of medium-size, frozen raw white-leg shrimp, consumers are willing to pay 30.54 yuan for guaranteed good quality, 19.84 yuan for guaranteed health safety, 12.16 yuan for eco-friendliness, and 3.53 yuan for all other guaranteed attributes. This means that if there is a shrimp product with $100 \%$ assurance of good quality, health safety, and eco-friendliness, consumers are willing to pay about 66 yuan; the maximum value for this type of shrimp. Shrimp with other sizes or product forms may have different values, but consumers allocate their WTP at 
the same ratio among these attributes which is about $46,30,18$, and $6 \%$, respectively. This fits the previous understanding of consumer preferences according to the Maslow's Hierarchy of Needs: Quality comes first as the basic food attribute for physiological needs; safety comes second to satisfy consumer security or health needs, and finally eco-friendliness works to fulfill the need for self-actualization.

Columns (2) to (7) are subsamples of the pooled data under different information scenarios. There is an observed value shifting among three factors when different information is provided. Column (2) represents the basic information scenario where consumers are WTP for 38.94 yuan, on average, for guaranteed quality of a shrimp product, nothing for guaranteed safety, and 10.1 yuan for eco-friendliness. All other factors contribute 3.44 yuan. Information for this subsample is similar to most Chinese consumers' knowledge level. When evaluating seafood with country of origin and eco-label information only, they tend to pay more when retailers guarantee higher quality. They choose not to believe the health safety guarantee because trust was broken after a few food safety incidents occurred. They are willing to pay a small amount for the eco-friendliness when it's guaranteed. Eco-friendliness is different from safety, because it is impossible to test and no negative incidents have occurred in China. Thus, consumers may choose to believe it. When private benefit information was provided (Column 3), consumers gained understanding of certification standards that could apply to both quality and health safety. Thus, WTP for guaranteed quality stays almost the same; but WTP for guaranteed safety increases significantly to 30.7 yuan. This change indicates the high demand for food safety, which would have been ignored if no private benefit information was provided. WTP for eco-friendliness is 
not significant. When public benefit information was added to private benefit information (Column 5), all three attributes are significant and positive. Total WTP remains at the same level as private benefit information, but the distribution changes slightly. Because consumers received more information about environmental protection from the certified farm, they put some resources from quality and safety into eco-friendliness.

For the other set of information treatments, public benefit information was provided first (Column 4), then private benefit information was added (Column 6). However, the results were not as significant as the first set. It could be caused by the small sample size - there are only 38 participants compared to 70 in the first set. The last column is the full information treatment, which is a pool of Columns (6) and (7). Outcomes show that consumers pay attention to all three factors, but they lower the weight on quality and allocate more resources to safety and eco-friendliness due to two pieces of additional information.

As a result of this data, some marketing suggestions were formed for promoting sustainably farmed seafood in China. First, when sustainably farmed seafood enters a new market in a developing country like China, it will be met by consumers with very limited seafood sustainability knowledge, as shown in the demographic survey in Chapter 3. This is because they have not been exposed to sustainable seafood certification standards or benefits guaranteed by the eco-label. More familiar information is mandated country of origin and production method information printed on the sales label in the grocery store. This is similar to our basic information scenario. An average Chinese retailer would not invest resources to provide additional 
information to educate consumers on food safety and eco-friendliness. They are correct, since a large portion of consumer WTP is proven spending on the guaranteed quality. The most effective marketing strategy for retailers is to convince their customers of their products' quality. However they are not able to predict neither the value of information nor the consumers' true WTP. When consumers are provided full information about sustainable aquaculture certification and promised guaranteed attributes, their hidden WTP for health, safety and eco-friendliness will be extracted, and the total WTP for the product will be much higher than with basic information only. To summarize, it is a two-step solution. First, educate consumers regarding sustainable aquaculture certification, preferably private benefit information first, then public benefit information. Second, guarantee the consumer a high percentage of one or a few attributes, since there is no single product that can guarantee $100 \%$ quality, safety, and eco-friendliness simultaneously. A certified aquaculture product, depending on what kind of certification it acquires, usually maintains a high level of one or a few attributes. For example, ASC certification has very stringent requirements for all three attributes; BAP certification has less stringent standards, but covers all the attributes; the Chinese local Non-harmless Agriculture certification focuses more on food safety; and Organic certification may advertise itself as highquality and eco-friendly. Finally, retailers should strive to avoid seafood fraud, whether intentional or accidental, as it is extremely difficult to rebuild Chinese consumers' trust in food safety.

\section{Conclusion}


Promotion of sustainable seafood has been slow in the Chinese market, despite constant industry efforts. Consumers and retailers are realizing the importance of sustainable seafood and are willing to play a role, but on the demand side, consumers have not received useful information when faced with a decision. On the supply end, retailers did not have full understanding of consumer preferences, such as how they allocate their money toward seafood attributes. Thus, the typical marketing strategy still focuses on quality attributes like freshness and taste, which falls short of developing the full value of sustainably farmed seafood. Gradually retailers lose interest in and incentives to sell sustainable seafood, because no or very limited profit is generated.

This study aims to provide scientific suggestions for promoting sustainable seafood in China based on consumer preference analysis. Built upon a popular experimental auction method, it incorporates consumers' subjective perceptions on basic seafood attributes in order to break down their WTP to the principal level. Multiple information treatments are designed to obtain more detailed solutions. A random expected utility model was used to construct the regression model, and the results indicate that with only basic information, such as country of origin and ecolabeling, consumers are willing to pay about 53 yuan (about US \$8) for 500 grams of farmed shrimp with a $100 \%$ guarantee of quality, safety, and eco-friendliness. Seventy-three percent of the WTP is due to the guaranteed quality, $0 \%$ for safety, and $18 \%$ for eco-friendliness. Providing private benefit information of certification increases consumers' total WTP to 69 yuan (about US \$10). Most of this comes from guaranteed safety. Lastly, providing additional information of public benefit does not 
increase consumers' total WTP, but successfully reallocates payment from quality to safety and eco-friendliness, with a $20 \%$ increase for eco-friendliness. In sum, for retailers interested in sustainably farmed seafood, it is essential to understand the requirement levels of quality, safety, and eco-friendliness provided by different seafood certification programs. They can then choose the appropriate products according to corporate short- and long-term seafood marketing objectives and goals. Based on these products, they then need to make a commitment to one or a few of the attributes. Finally, they need to educate their consumers with the private and public benefit information about the different sustainable seafood certifications. 
Table 4.1 Summary Statistics of Main Variables

\begin{tabular}{llllll}
\hline \hline Variable & Obs & Mean & Std. Dev. & Min & Max \\
\hline Bid & 1296 & 37.594 & 21.345 & 0 & 200 \\
Quality perception & 1296 & 0.649 & 0.203 & 0.05 & 1 \\
Safety perception & 1296 & 0.641 & 0.224 & 0.05 & 1 \\
$\begin{array}{l}\text { Eco-friendliness } \\
\text { perception }\end{array}$ & 1296 & 0.536 & 0.263 & 0 & 1 \\
\hline \hline
\end{tabular}




\section{Figure 4.1. Summary of Consumers' Perceptions and Bids by Product Type and Information}
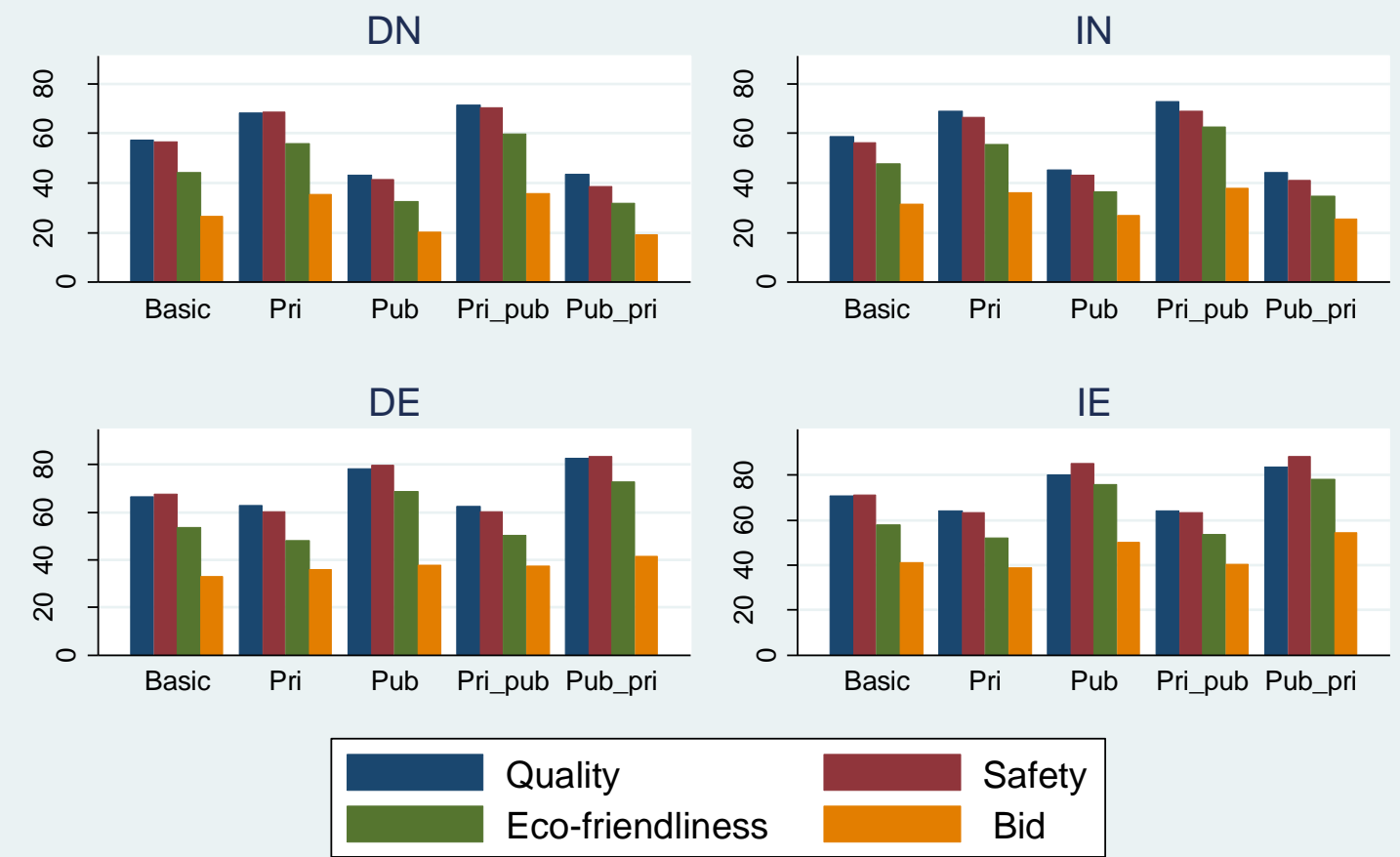

Notes: DN indicates domestic/non-labeled shrimp; DE indicates domestic/eco-labeled shrimp; IN indicates imported/non-labeled shrimp; IE indicates imported/eco-labeled shrimp. Basic information includes whether or not the products are imported or eco-labeled. Private benefit and public benefit are both single pieces of information. Public+private and private+public are both full pieces information, but given in different sequences. The unit for perceptions is percentage, and the unit for bid is the Chinese yuan. 
Table 4.2. Consumer WTP for Quality, Safety, and Eco-friendliness by Information Treatment

\begin{tabular}{|c|c|c|c|c|c|c|c|}
\hline & (1) Pooled & (2) Basic & (3) Private & (4) Public & (5) Pri+Pub & (6) Pub+Pri & (7) Full \\
\hline VARIABLES & & & & $\Delta(\mathrm{Bid})$ & & & \\
\hline \multirow[t]{2}{*}{$\Delta$ (Quality) } & $30.536 * * *$ & $38.937 * * *$ & $35.081 * * *$ & $40.401 * * *$ & $23.827 * *$ & $33.899 * *$ & $24.185^{* * *}$ \\
\hline & (3.608) & (6.776) & (7.721) & (12.962) & (11.122) & (13.166) & (8.504) \\
\hline \multirow[t]{2}{*}{$\Delta$ (Safety) } & $19.839 * * *$ & 6.771 & $30.704 * * *$ & 4.671 & $27.326^{* *}$ & $19.496^{*}$ & $21.382 * *$ \\
\hline & $(3.465)$ & $(6.142)$ & (8.992) & (10.983) & (11.857) & (11.302) & (8.696) \\
\hline \multirow[t]{2}{*}{$\Delta($ Eco $)$} & $12.160 * * *$ & $10.100 * *$ & 1.339 & 8.079 & $14.956^{*}$ & 2.096 & $13.354 * *$ \\
\hline & (2.154) & (4.611) & (7.177) & $(5.976)$ & $(8.180)$ & $(5.175)$ & $(5.458)$ \\
\hline \multirow[t]{2}{*}{ Constant } & $3.531 * * *$ & $3.437 * * *$ & $3.315 * * *$ & $3.029 * *$ & $4.889 * * *$ & $3.363 * *$ & $6.217 * * *$ \\
\hline & $(0.331)$ & $(0.509)$ & $(0.564)$ & (1.212) & $(0.739)$ & (1.662) & (1.470) \\
\hline Observations & 1,296 & 432 & 280 & 152 & 280 & 152 & 324 \\
\hline R-squared & 0.542 & 0.478 & 0.675 & 0.427 & 0.652 & 0.376 & 0.465 \\
\hline $\mathrm{N}$ of subject & 108 & 108 & 70 & 38 & 70 & 38 & 108 \\
\hline
\end{tabular}

Notes: This is a summation of six individual regressions of consumer bidding differences and their perception difference of quality, safety, and eco-friendliness under various information treatments. Column (1) uses the pooled data of all information treatments. Basic information includes: country of origin and certification, no detailed information is provided. Private benefit and public benefit are both single pieces of information that state different standards of the eco-label. Public+private and private+public are both full pieces information, but given in different sequences. The coefficients represent consumer WTP for quality, safety, and eco-friendliness. Standard errors in parentheses. $* * * \mathrm{p}<0.01, * * \mathrm{p}<0.05, * \mathrm{p}<0.1$. 


\section{CHAPTER 5}

\section{CONCLUSIONS}

This paper focuses on the sustainably farmed seafood market in China, using both real market data and non-hypothetical experimental auction data to evaluate the impact of country of origin, eco-label, and certification standard information on consumer preferences. By incorporating consumers' subjective perceptions of quality, safety, and eco-friendliness, we succeed in determining consumer WTP for products into their WTP for basic product attributes. Research findings can be used to assist retailers in designing marketing strategies. This can also provide policy implications for governmental agencies in fishery and food industries.

The first study takes advantage of the well-developed online retail market in China and creates a data set consisting of weekly price and product characteristic information. A log-linear regression suggests that seafood safety is the biggest concern of Chinese consumers, while an eco-label does not have a positive influence. When there is no safety information, there are 6-14\% premiums for imported over domestic shrimp. For domestic shrimp, there is a $36 \%$ premium with safety information, while safety information does not generate a premium for imported products. Results indicate the importance of providing a safety guarantee for domestic shrimp. Without safety information, consumers would rather spend more on imported products.

Our second study uses an experimental auction method and adds private benefit and public benefit information from certification standards into the experiment in 
order to simulate different market scenarios. Consumer WTP for product attributes tested in this study should be more accurate and reliable since we can control how they receive information and ensure they consider it when making decisions. A randomeffects panel data regression suggests that for eco-labeled products, domestic or imported, it is best to provide public and then private benefit information. While for imported/non-labeled products, providing private benefit information first then public benefit information will lead to higher prices. For domestic/non-labeled products, our results show private benefit information will increase the consumer WTP. This is still a debatable result, since it is not reasonable for consumers to pay more for non-labeled products when they have certification information.

The third study is the continuation of the experiment. We incorporate consumers' subjective perceptions of product quality, safety, and eco-friendliness into the analysis to provide a more detailed understanding of their preferences. The regression model is built on a random expected utility model. By estimating the effects of consumer perception variations in those three basic attributes on their bidding variations, we obtained the marginal utility on income that consumers place on each attribute-WTP for product quality, safety, and eco-friendliness. Results indicate that with only basic information of country of origin and eco-labeling, consumers are willing to pay about 53 yuan for 500 grams of farmed shrimp with a $100 \%$ guarantee of quality, safety, and eco-friendliness. Seventy-three percent of their WTP is due to guaranteed quality, 0\% for safety, and $18 \%$ for eco-friendliness. Recalling our first study of the online retail market, consumers received only basic information. The average price was 57 yuan per 500 grams, which is surprisingly similar to our predicted result. Providing private 
benefit information of certification increases consumer total WTP to 69 yuan (about US \$10). Most of this comes from the payment for guaranteed safety. Lastly, providing additional information of public benefit does not increase consumers' total WTP, but successfully reallocates the payment from quality to safety and ecofriendliness, with a $20 \%$ increase for eco-friendliness.

Combining the three studies, we can draw the following conclusions. Imported seafood is the Chinese consumers' first choice when there is no safety information. Guaranteed safety can generate a high premium on domestic seafood, but not imported. An eco-label does not generate a price premium in the current market, but consumers are willing to pay for it as long as they are educated with the public benefit information of the sustainable certification. Full certification information can significantly increase consumer WTP for sustainably farmed seafood, especially for safety and eco-friendliness. In sum, this study confirms the great potential of the sustainably farmed seafood market in China. Seafood producers and retailers should join sustainable seafood programs based on their own needs, but most importantly educate their consumers about the private and public benefits they can enjoy through consumption of sustainably farmed seafood products. 


\section{BIBLIOGRAPHY}

ASC. 2017. "Aquaculture Stewardship Council | ASC Discusses the Risks and Challenges in Aquaculture." Accessed June 13, 2017. http://www.ascaqua.org/index.cfm?act=update.detail\&uid=315\&lng=1.

Asche, Frank, Thomas A. Larsen, Martin D. Smith, Geir Sogn-Grundvåg, and James A. Young. 2015. "Pricing of Eco-Labels with Retailer Heterogeneity." Food Policy 53 (May):82-93. https://doi.org/10.1016/j.foodpol.2015.04.004.

BAP. 2017. "Best Aquaculture Practices." Best Aquaculture Practices Certification. Accessed October 19, 2017. https://www.bapcertification.org/.

Belton, Ben, Francis Murray, James Young, Trevor Telfer, and David C. Little. 2010. "Passing the Panda Standard: A TAD off the Mark?" AMBIO: A Journal of the Human Environment 39 (1):2-13. https://doi.org/10.1007/s13280-009-0009-4.

Blomquist, Johan, Valerio Bartolino, and Staffan Waldo. 2015. "Price Premiums for Providing Eco-Labelled Seafood: Evidence from MSC-Certified Cod in Sweden." Journal of Agricultural Economics 66 (3):690-704. https://doi.org/10.1111/14779552.12106.

Brécard, Dorothée, Lucas Sterenn, Pichot Nathalie, and Frédéric Salladarré. 2012. "Consumer Preferences for Eco, Health and Fair Trade Labels. An Application to Seafood Product in France." Journal of Agricultural \& Food Industrial Organization 10 (1):1-32.

Bronnmann, Julia, and Frank Asche. 2016. "The Value of Product Attributes, Brands and Private Labels: An Analysis of Frozen Seafood in Germany.” Journal of Agricultural Economics 67 (1):231-44. https://doi.org/10.1111/1477-9552.12138.

Bush, S. R., B. Belton, D. Hall, P. Vandergeest, F. J. Murray, S. Ponte, P. Oosterveer, et al. 2013. "Certify Sustainable Aquaculture?" Science 341 (6150):1067-68. https://doi.org/10.1126/science.1237314.

Cao, L., Chen, Y., Dong, S., Hanson, A., Huang, B., Leadbitter, D., Little, D.C., Pikitch, E.K., Qiu, Y., Mitcheson, Y.S. de, Sumaila, U.R., Williams, M., Xue, G., Ye, Y., Zhang, W., Zhou, Y., Zhuang, P., Naylor, R.L., 2017. "Opportunity for Marine Fisheries Reform in China." Proceedings of the National Academy of Sciences 114 (3):435-42. https://doi.org/10.1073/pnas.1616583114.

Cao, Ling, Rosamond Naylor, Patrik Henriksson, Duncan Leadbitter, Marc Metian, Max Troell, and Wenbo Zhang. 2015. "China's Aquaculture and the World's Wild Fisheries.” Science 347 (6218):133-35. https://doi.org/10.1126/science.1260149. 
Chen, Shangji. 2009. "Marginal Sea of China." Encyclopedia of China. Beijing:

Encyclopedia of China Publishing House.

http://art.tze.cn/Refbook/book.aspx?bi=m.20080213-m300-w001-

034\&cult=CN\&Token=8F00EC120B0672FDDCF53B30765A0445.

Chen, Xinjun. 2014. "An Introduction to China Fishery Resources and Fishing Grounds." In Fishery Resources and Fishing Grouds, Second Edition. Beijing: Ocean Press.

Chen, Yuji, and Chongle Zhang. 2009. "Coast of China." Encyclopedia of China. Beijing: Encyclopedia of China Publishing House.

CIA. 2017. "The World Factbook.” Accessed September 8, 2017. https://www.cia.gov/library/publications/the-world-factbook/geos/ch.html.

Darby, Michael R., and Edi Karni. 1973. "Free Competition and the Optimal Amount of Fraud." Journal of Law and Economics 16 (1):67-88.

Fabinyi, Michael. 2012. "Historical, Cultural and Social Perspectives on Luxury Seafood Consumption in China." Environmental Conservation 39 (1):83-92. https://doi.org/10.1017/S0376892911000609.

Fabinyi, Michael. 2016. "Sustainable Seafood Consumption in China." Marine Policy 74 (December):85-87. https://doi.org/10.1016/j.marpol.2016.09.020.

Fabinyi, Michael, and Neng Liu. 2016. "The Social Context of the Chinese Food System: An Ethnographic Study of the Beijing Seafood Market." Sustainability 8 (3):244. https://doi.org/10.3390/su8030244.

FAO. 2011. "FAO Fisheries \& Aquaculture Statistics." FAO Fisheries \& Aquaculture Statistics. Accessed October 19, 2017. http://www.fao.org/fishery/statistics/en.

FAO. 2016. "FAO Fisheries \& Aquaculture - The State of World Fisheries and Aquaculture (SOFIA)." Accessed October 19, 2017. http://www.fao.org/fishery/sofia/en.

FAO. 2017 "Food Supply - Livestock and Fish Primary Equivalent." Accessed September 19, 2017. http://www.fao.org/faostat/en/\#data/CL.

FDA. 2017. "Hazard Analysis Critical Control Point (HACCP)." Hazard Analysis

Critical Control Point (HACCP). Accessed October 19, 2017. https://www.fda.gov/food/guidanceregulation/haccp/.

Fonner, Robert, and Gil Sylvia. 2015. "Willingness to Pay for Multiple Seafood Labels in a Niche Market.” Marine Resource Economics 30 (1):51-70. https://doi.org/10.1086/679466. 
Ford, Gary T., Darlene B. Smith, and John L. Swasy. 1988. "An Empirical Test of the Search, Experience and Credence Attributes Framework." ACR North American Advances NA-15. http://acrwebsite.org/volumes/6817/volumes/v15/NA-15.

Gopalakrishnan, Sathya, Martin D. Smith, Jordan M. Slott, and A. Brad Murray. 2011. "The Value of Disappearing Beaches: A Hedonic Pricing Model with Endogenous Beach Width." Journal of Environmental Economics and Management 61 (3):297-310. https://doi.org/10.1016/j.jeem.2010.09.003.

Greenpeace, East Asia. 2017. "Report of China's Ocean Fisheries of Juveniles and Forage Fish and Its Implications to the Development of China's Sustainable Fisheries.” Beijing, China: Greenpeace, East Asia. http://www.greenpeace.org.cn/news/.

Grunert, Klaus G. 2002. "Current Issues in the Understanding of Consumer Food Choice." Trends in Food Science \& Technology 13 (8):275-85. https://doi.org/10.1016/S0924-2244(02)00137-1.

Gulbrandsen, Lars H. 2006. "Creating Markets for Eco-Labelling: Are Consumers Insignificant?” International Journal of Consumer Studies 30 (5):477-89. https://doi.org/10.1111/j.1470-6431.2006.00534.x.

Gutierrez, Nicolas L., Omar Defeo, Simon R. Bush, Doug S. Butterworth, Cathy A. Roheim, and Andre E. Punt. 2016. "The Current Situation and Prospects of Fisheries Certification and Ecolabelling." Fisheries Research, Special Issue: Fisheries certification and Eco-labeling: Benefits, Challenges and Solutions, 182 (October):1-6. https://doi.org/10.1016/j.fishres.2016.05.004.

Han, D., Shan, X., Zhang, W., Chen, Y., Wang, Q., Li, Z., Zhang, G., Xu, P., Li, J., Xie, S., Mai, K., Tang, Q., De Silva, S.S., 2016. “A Revisit to Fishmeal Usage and Associated Consequences in Chinese Aquaculture." Reviews in Aquaculture, October, n/a-n/a. https://doi.org/10.1111/raq.12183.

Han, Yang, and Xiang Bi. 2016. “Consumers' Willingness to Pay Price Premium for Seafood: The Effects of Food Safety Incidents in China." 2016 Annual Meeting, February 6-9, 2016, San Antonio, Texas. Southern Agricultural Economics Association. https://ideas.repec.org/p/ags/saea16/230120.html.

Huntington, T.C., and Mohammad Hasan. 2009. "Fish as Feed Inputs for AquaculturePractices, Sustainability and Implications: A Global Synthesis." Fisheries and Aquaculture Technical Paper 518 (January):1-61.

Jaffry, Shabbar, Helen Pickering, Yaseen Ghulam, David Whitmarsh, and Prem Wattage. 2004. "Consumer Choices for Quality and Sustainability Labelled Seafood Products in the UK." Food Policy 29 (3):215-28. https://doi.org/10.1016/j.foodpol.2004.04.001. 
Johnston, Robert J., Cathy R. Wessells, Holger Donath, and Frank Asche. 2001. "Measuring Consumer Preferences for Ecolabeled Seafood: An International Comparison." Journal of Agricultural and Resource Economics 26 (1):20-39.

Johnston, Robert J., Cathy Roheim Wessells, Holger Donath, and Frank Asche. 2000. Measuring Consumer Preferences for Ecolabeled Seafood: An International Comparison. SNF/Centre for Fisheries Economics. https://brage.bibsys.no/xmlui/handle/11250/165263.

Jonell, Malin, Michael Phillips, Patrik Rönnbäck, and Max Troell. 2013. "EcoCertification of Farmed Seafood: Will It Make a Difference?" Ambio 42 (6):65974. https://doi.org/10.1007/s13280-013-0409-3.

Kagel, John, Ronald Harstad, and Dan Levin. 1987. "Information Impact and Allocation Rules in Auctions with Affiliated Private Values: A Laboratory Study." Econometrica 55 (6):1275-1304.

Lancaster, Kelvin J. 1966. “A New Approach to Consumer Theory.” Journal of Political Economy 74 (2):132-57. https://doi.org/10.1086/259131.

Loureiro, Maria L., Jill J. McCluskey, and Ron C. Mittelhammer. 2001. "Assessing Consumer Preferences for Organic, Eco-Labeled, and Regular Apples." Journal of Agricultural and Resource Economics 26 (2):404-16.

Lusk, Jayson L. 2003. "Using Experimental Auctions for Marketing Applications: A Discussion." Journal of Agricultural and Applied Economics 35 (2):349-360. https://doi.org/10.1017/S1074070800021313.

Lusk, Jayson L., Ty Feldkamp, and Ted C. Schroeder. 2004. "Experimental Auction Procedure: Impact on Valuation of Quality Differentiated Goods." American Journal of Agricultural Economics 86 (2):389-405. https://doi.org/10.1111/j.0092-5853.2004.00586.x.

Lusk, Jayson L., and Ted C. Schroeder. 2004. "Are Choice Experiments Incentive Compatible? A Test with Quality Differentiated Beef Steaks." American Journal of Agricultural Economics 86 (2):467-82.

Lusk, Jayson L., Ted C. Schroeder, and Glynn T. Tonsor. 2014. "Distinguishing Beliefs from Preferences in Food Choice." European Review of Agricultural Economics 41 (4):627-55. https://doi.org/10.1093/erae/jbt035.

O'Brien, Kelly A., and Mario F. Teisl. 2004. "Eco-Information and Its Effect on Consumer Values for Environmentally Certified Forest Products." Journal of Forest Economics 10 (2):75-96. https://doi.org/10.1016/j.jfe.2004.05.001. 
Onozaka, Yuko, Hirotsugu Uchida, Tamaki Morita, and Shunsuke Managi. 2010. "Uninformed or Uninterested? Surveys Examine Japanese Consumers' Interest in Sustainable Seafood." Global Aquaculture Advocate 1 (1):58-60.

Ponte, Stefano. 2012. "The Marine Stewardship Council (MSC) and the Making of a Market for 'Sustainable Fish." Journal of Agrarian Change 12 (2-3):300-315. https://doi.org/10.1111/j.1471-0366.2011.00345.x.

Ready, Richard C., and Charles W. Abdalla. 2005. "The Amenity and Disamenity Impacts of Agriculture: Estimates from a Hedonic Pricing Model." American Journal of Agricultural Economics 87 (2):314-26. https://doi.org/10.1111/j.14678276.2005.00724.x.

Roheim, Cathy A., Frank Asche, and Julie Insignares Santos. 2011. "The Elusive Price Premium for Ecolabelled Products: Evidence from Seafood in the UK Market." Journal of Agricultural Economics 62 (3):655-68. https://doi.org/10.1111/j.14779552.2011.00299.x.

Roheim, Cathy A., Pratheesh Omana Sudhakaran, and Catherine A. Durham. 2012. "Certification of Shrimp and Salmon for Best Aquaculture Practices: Assessing Consumer Preferences in Rhode Island." Aquaculture Economics \& Management 16 (3):266-86. https://doi.org/10.1080/13657305.2012.713075.

Rosen, Sherwin. 1974. "Hedonic Prices and Implicit Markets: Product Differentiation in Pure Competition." Journal of Political Economy 82 (1):34-55. https://doi.org/10.1086/260169.

Sander, Heather A., and Stephen Polasky. 2009. "The Value of Views and Open Space: Estimates from a Hedonic Pricing Model for Ramsey County, Minnesota, USA." Land Use Policy 26 (3):837-45. https://doi.org/10.1016/j.landusepol.2008.10.009.

Sogn-Grundvåg, Geir, Thomas Andre Larsen, and James A. Young. 2014. "Product Differentiation with Credence Attributes and Private Labels: The Case of Whitefish in UK Supermarkets." Journal of Agricultural Economics 65 (2):36882. https://doi.org/10.1111/1477-9552.12047.

Stemle, Adam, Hirotsugu Uchida, and Cathy A. Roheim. 2016. "Have Dockside Prices Improved after MSC Certification? Analysis of Multiple Fisheries." Fisheries Research, Special Issue: Fisheries certification and Eco-labeling: Benefits, Challenges and Solutions, 182 (Supplement C):116-23. https://doi.org/10.1016/j.fishres.2015.07.022.

The World Bank. 2016. "Household Final Consumption Expenditure (Annual \% Growth) | Data." Accessed October 19, 2017. http://data.worldbank.org/indicator/NE.CON.PRVT.KD.ZG?locations=CN. 
The World Bank. 2017. “GDP (Current US\$) | Data.” Accessed October 19, 2017. https://data.worldbank.org/indicator/NY.GDP.MKTP.CD?end=2015\&locations= CN\&start=1995.

Uchida, Hirotsugu, Yuko Onozaka, Tamaki Morita, and Shunsuke Managi. 2014a. "Demand for Ecolabeled Seafood in the Japanese Market: A Conjoint Analysis of the Impact of Information and Interaction with Other Labels." Food Policy 44 (February):68-76. https://doi.org/10.1016/j.foodpol.2013.10.002.

Uchida, Hirotsugu, Cathy A. Roheim, Hiroki Wakamatsu, and Christopher M. Anderson. 2014b. "Do Japanese Consumers Care about Sustainable Fisheries? Evidence from an Auction of Ecolabelled Seafood." Australian Journal of Agricultural and Resource Economics 58 (2):263-80. https://doi.org/10.1111/1467-8489.12036.

Wang, Xiaojin. 2016. "The Value of Country-of-Origin and Wild-Caught Labels: A Hedonic Analysis of Shrimp Retail Prices in the United States.” 2016 Annual Meeting, February 6-9, 2016, San Antonio, Texas. Southern Agricultural Economics Association. http://econpapers.repec.org/paper/agssaea16/230197.htm.

Wessells, Cathy R., Robert J. Johnston, and Holger Donath. 1999. “Assessing Consumer Preferences for Ecolabeled Seafood: The Influence of Species, Certifier, and Household Attributes." American Journal of Agricultural Economics 81 (5):1084-89. https://doi.org/10.2307/1244088.

Wessells, Cathy Roheim. 2002. "The Economics of Information: Markets for Seafood Attributes." Marine Resource Economics 17 (2):153-62. https://doi.org/10.1086/mre.17.2.42629358.

Xiamen Statistics Bureau. 2017. "Yearly Statistics of Xiamen Special Economic District 2016." 2017. http://www.stats-xm.gov.cn/2016/main0.htm.

Xu, Pei, Yinchu Zeng, Quentin Fong, Todd Lone, and Yuanyuan Liu. 2012. “Chinese Consumers' Willingness to Pay for Green- and Eco-Labeled Seafood." Food Control 28 (1):74-82. https://doi.org/10.1016/j.foodcont.2012.04.008.

Zeithaml, Valarie A. 1988. "Consumer Perceptions of Price, Quality, and Value: A Means-End Model and Synthesis of Evidence.” Journal of Marketing 52 (3):2-22. https://doi.org/10.2307/1251446. 